OPEN ACCESS

Edited by:

Robert J. Harvey,

University College London, UK

Reviewed by:

Jochen C. Meier,

Technical University Braunschweig,

Germany

Julia Dallman,

University of Miami, USA

${ }^{*}$ Correspondence:

Kazutoyo Ogino

kogino@chem.aoyama.ac.jp;

Hiromi Hirata

hihirata@chem.aoyama.ac.jp

Received: 31 March 2016 Accepted: 13 June 2016

Published: 29 June 2016

Citation:

Ogino K and Hirata H (2016) Defects of the Glycinergic Synapse

in Zebrafish.

Front. Mol. Neurosci. 9:50 doi: 10.3389/fnmol.2016.00050

\section{Defects of the Glycinergic Synapse in Zebrafish}

\author{
Kazutoyo Ogino* and Hiromi Hirata* \\ Department of Chemistry and Biological Science, College of Science and Engineering, Aoyama Gakuin University, \\ Sagamihara, Japan
}

Glycine mediates fast inhibitory synaptic transmission. Physiological importance of the glycinergic synapse is well established in the brainstem and the spinal cord. In humans, the loss of glycinergic function in the spinal cord and brainstem leads to hyperekplexia, which is characterized by an excess startle reflex to sudden acoustic or tactile stimulation. In addition, glycinergic synapses in this region are also involved in the regulation of respiration and locomotion, and in the nociceptive processing. The importance of the glycinergic synapse is conserved across vertebrate species. A teleost fish, the zebrafish, offers several advantages as a vertebrate model for research of glycinergic synapse. Mutagenesis screens in zebrafish have isolated two motor defective mutants that have pathogenic mutations in glycinergic synaptic transmission: bandoneon (beo) and shocked (sho). Beo mutants have a loss-of-function mutation of glycine receptor (GlyR) $\beta$-subunit b, alternatively, sho mutant is a glycinergic transporter 1 (GlyT1) defective mutant. These mutants are useful animal models for understanding of glycinergic synaptic transmission and for identification of novel therapeutic agents for human diseases arising from defect in glycinergic transmission, such as hyperekplexia or glycine encephalopathy. Recent advances in techniques for genome editing and for imaging and manipulating of a molecule or a physiological process make zebrafish more attractive model. In this review, we describe the glycinergic defective zebrafish mutants and the technical advances in both forward and reverse genetic approaches as well as in vivo visualization and manipulation approaches for the study of the glycinergic synapse in zebrafish.

Keywords: startle disease, glycine, receptor, synapse, transporter, zebrafish

\section{OVERVIEW OF GLYCINERGIC NEUROTRANSMISSION IN THE MAMMALIAN NERVOUS SYSTEM}

Glycine is a major inhibitory neurotransmitter in the brainstem and spinal cord. The glycinergic transmission plays important roles in the reflex and the control of rhythmic motor behaviors such as locomotion and breathing (Schmid et al., 1991, 1996; Gomeza et al., 2003a; Grillner, 2003; Callister and Graham, 2010), as well as nociceptive processing (Baba et al., 2001; Ahmadi et al., 2002; Harvey et al., 2004; Zeilhofer, 2005). Glycine receptors (GlyRs) are also expressed in the retina (Sassoè-Pognetto et al., 1994; Haverkamp et al., 2003, 2004; Jusuf et al., 2005; Heinze et al., 2007) and various regions of the brain, such as amygdala (McCool and Botting, 2000; McCool and Farroni, 2001), hippocampus (Malosio et al., 1991; Chattipakorn and McMahon, 2002, 2003; Brackmann et al., 2004; Danglot et al., 2004; Eichler et al., 2009; Jonsson et al., 2012; 
Chen et al., 2014; Winkelmann et al., 2014; Çalişkan et al., 2016), midbrain (Malosio et al., 1991; Mangin et al., 2002; Jonsson et al., 2012), neocortex (Malosio et al., 1991; Jonsson et al., 2012; Salling and Harrison, 2014), to regulate neuronal network excitability. GlyRs are pentameric ligand-gated chloride channels taking the form of $\alpha$-subunit homopentamers or $\alpha \beta$-subunit heteropentamars. The $\alpha$-subunit is ligand-binding subunit (Becker et al., 1988; Grenningloh et al., 1990a,b; Kuhse et al., 1990), whereas the $\beta$-subunit binds to synaptic gephyrin scaffold consisting of tens to hundreds gephyrin molecules, thereby the $\alpha \beta$ heteromeric GlyRs can be accumulated at postsynaptic sites (Kirsch et al., 1993; Meyer et al., 1995; Feng et al., 1998; Hanus et al., 2004; Sola et al., 2004; Grudzinska et al., 2005; Kim et al., 2006; Calamai et al., 2009; Herweg and Schwarz, 2012; Specht et al., 2013). However, the postsynaptic localization of GlyR is not permanent. GlyRs are constantly exchanged between synaptic sites and extrasynaptic plasmamembrane by means of lateral diffusion, and alterations of the diffusion properties have been considered to be mechanisms involved in the synaptic plasticity (Meier et al., 2001; Dahan et al., 2003; Ehrensperger et al., 2007; Lévi et al., 2008; Calamai et al., 2009; Specht et al., 2011). Furthermore, the postsynaptic gephyrin scaffold is involved in regulation of the properties for synaptic plasticity in both glycinergic synapses and GABAergic synapses through interactions with various proteins (Fritschy et al., 2008; Tyagarajan and Fritschy, 2014).

Two possible stoichiometric models of the heteromeric GlyR have been proposed from research using purified GlyR subunits: $3 \alpha 2 \beta$ and $2 \alpha 3 \beta$ (Langosch et al., 1988; Burzomato et al., 2003; Grudzinska et al., 2005). Durisic et al. (2012) published data supporting $3 \alpha 2 \beta$ stoichiometry by single-molecule stepwise photo-bleaching: whereas a homomeric channel of fluorescent protein-tagged $\alpha$ subunits exhibited bleaching by a five-step reduction of fluorescence, a heteromeric channel containing the fluorescent protein-tagged $\alpha$-subunits exhibited bleaching by a three-step reduction (Durisic et al., 2012). However, another group proposed the likelihood of the $2 \alpha 3 \beta$ stoichiometry based on the observation of antibody bounded receptor consisting of FLAG-tagged $\alpha$-subunit and His-tagged $\beta$-subunit using singlemolecule resolution atomic force microscopy (Yang et al., 2012). The single-molecular imaging showed that the maximum binding number of antibodies to each of the tag, anti-FLAG antibodies and anti-His antibodies could bind to the receptor up to two and three, respectively. The exact stoichiometry of the $\alpha \beta$ GlyR heteromer thus remains a point of contention, and requires further investigation. Although the formation of a homomeric $\beta$ GlyR has also been hypothesized, biochemical evidence has indicated that $\beta$ subunits do not form pentamers (Griffon et al., 1999), and an electrophysiological analysis showed that recombinant expression of only the $\beta$ subunit in HEK-293 cells does not result in glycine-gated currents (Bormann et al., 1993).

In contrast to heteromeric GlyR, homomeric GlyRs are mainly distributed in the extrasynaptic area or presynaptic terminal in the brain and spinal cord (Turecek and Trussell, 2001; Jeong et al., 2003; Ye et al., 2004; Wang et al., 2005; Deleuze et al., 2005; Eichler et al., 2008; Kubota et al., 2010; Hruskova et al., 2012; Kunz et al., 2012; Avila et al., 2013; Chen et al., 2014;
Salling and Harrison, 2014; Winkelmann et al., 2014). The extrasynaptic homomeric GlyRs are activated by ambient glycine or taurine, thereby tonic glycinergic current that contributed to regulation of neuronal excitability both in mature and immature neural tissue is evoked (Chattipakorn and McMahon, 2003; Wang et al., 2005; Eichler et al., 2008; Chen et al., 2014; Maguire et al., 2014; Salling and Harrison, 2014). In contrast to the GlyRs on mature neurons, GlyRs on immature neurons typically induce depolarizing chloride efflux in accordance with the chloride gradient that is opposite to that of mature neurons (Reichling et al., 1994; Flint et al., 1998; Ben-Ari, 2002). The inverted chloride gradient is formed and maintained by $\mathrm{Na}^{+}$$\mathrm{K}^{+}-2 \mathrm{Cl}^{-}$cotransporter (NKCC1), which import chloride ions into the cell. On immature neurons, presynaptic GlyRs facilitate neurotransmitter release through activation of voltage gated calcium channel (VGCC) (Turecek and Trussell, 2001; Jeong et al., 2003; Ye et al., 2004; Eichler et al., 2009; Kunz et al., 2012; Winkelmann et al., 2014). Similarly, tonic activation of the extrasynaptic GlyR on the developing immature neurons induced $\mathrm{Ca}^{2+}$ transients through VGCCs. The activation of VGCCs have been considered to promote the synaptic accumulation of GlyRs (Kirsch and Betz, 1998; Kneussel and Betz, 2000) or to regulate the development of cortical neurons by promoting migration (Avila et al., 2013, 2014). The $\mathrm{Ca}^{2+}$ transients may also be involved in the $\mathrm{K}^{+} \mathrm{Cl}^{-}$cotransporter type 2 (KCC2) expression (Brustein et al., 2013; Allain et al., 2015). It is generally accepted, the activity of NKCC1 declines with progress of development, whereas activity of KCC2, which establishes the chloride gradient of mature neurons by extrusion of chloride ions, becomes predominant (Kanaka et al., 2001; Ben-Ari, 2002; Mikawa et al., 2002; Wang et al., 2002; Delpy et al., 2008). The KCC2 activity is necessary for glycinergic synapse maturation. Knockdown of KCC2 impaired cluster formation of GlyR $\alpha 1$ subunit (adulttype subunit) and gephyrin in cultured spinal neurons, whereas $\alpha 2$ subunit (neonatal type subunit) cluster formation was not affected by the KCC2 knockdown (Schwale et al., 2016). In addition to the developmental role, the tonic depolarizing current contributes to regulate the neuronal excitability in immature hippocampus (Chattipakorn and McMahon, 2003; Eichler et al., 2008; Chen et al., 2014).

The $\alpha$ homomeric GlyR current can be pharmacologically distinguished from that of the $\alpha \beta$ heteromeric GlyR by picrotoxin, a GlyR inhibitor: picrotoxin has a 100-fold greater affinity for the $\alpha$ homomeric GlyR than the $\alpha \beta$ heteromeric GlyR, such that the $\alpha$ homomeric GlyR is specifically blocked by picrotoxin at low concentrations (Pribilla et al., 1992; Mangin et al., 2002). These currents can also be distinguished by electrophysiological analysis, because the conductance mediated by $\alpha 1$ or $\alpha 3$ homomeric GlyR is larger than that of $\alpha 1 \beta$ or $\alpha 3 \beta$ heteromeric GlyR (Takahashi et al., 1992; Bormann et al., 1993; Rajendra et al., 1995; Beato et al., 2002; Burzomato et al., 2004; Zhang et al., 2015).

In addition to the GlyR agonist, glycine acts as co-agonist of $N$-methyl-D-aspartate receptor (NMDAR) (Johnson and Ascher, 1987). The simultaneous binding of glutamate and the co-agonist is required to activate the NMDAR (Johnson and Ascher, 1987; Furukawa et al., 2005; Paoletti and Neyton, 2007). Although the 
physiological significance of co-agonist glycine is unclear, the recent works have reported the involvement in induction of LTD (Papouin et al., 2012), morphogenesis of dopaminergic neurons (Schmitz et al., 2009, 2013).

\section{Mammalian Glycine Receptor Subunits}

There exist four GlyR $\alpha$ subunit genes (GLRA1, GLRA2, GLRA3, GLRA4) and one $\beta$ subunit gene (GLRB) in humans and rodents (Grenningloh et al., 1987, 1990b; Kuhse et al., 1990, 1991; Harvey et al., 2000), although the human GLRA4 is not expressed due to a premature stop codon in this gene, thus human GLRA4 is pseudogene (Simon et al., 2004). Electrophysiological studies on cultured cells expressing mammalian GlyR subunits have shown that the difference in conductance and kinetics between $\alpha 1 \beta / \alpha 3 \beta$ and $\alpha 2 \beta$, the conductance of $\alpha 2 \beta$ is larger than that of the former, activation kinetics of $\alpha 2$ homomeric and $\alpha 2 \beta$ heteromeric is slower than $\alpha 1 / \alpha 3$ containing receptor (Takahashi et al., 1992; Bormann et al., 1993; Rajendra et al., 1995; Beato et al., 2002; Mangin et al., 2003; Burzomato et al., 2004; Zhang et al., 2015). The adult mammalian hindbrain and spinal cord predominantly expresses the $\alpha 1$ (GLRA1) and $\beta$ (GLRB) GlyR subunits (Malosio et al., 1991; Singer et al., 1998; Jonsson et al., 2012; Weltzien et al., 2012). Hence, it is assumed that heteromeric $\alpha 1 \beta$ GlyRs mediate a majority of glycinergic neurotransmission in these matured neural tissues. In this physiological context, it has been shown that glycinergic synaptic transmission is important for the generation of rhythmic motor behaviors. Functional loss of human GLRA1 due to missense, nonsense, or frame-shift mutation leads to the development of a hyperekplexia syndrome that is characterized by various exaggerated startle responses to unexpected acoustic or tactile stimuli, as well as neonatal apnea (Harvey et al., 2008a; Davies et al., 2010; Bode and Lynch, 2014). In addition, mutations that are associated with hyperekplexia syndrome have been identified in the GlyR $\beta$ subunit gene (Rees et al., 2002; Al-Owain et al., 2012; Chung et al., 2013; James et al., 2013; Mine et al., 2013; Rizk and Mahmoud, 2014), the gephyrin gene (Rees et al., 2003), and the collybistin gene (Harvey et al., 2004). Furthermore, mutation of the glycine transporter 2 (GlyT2) gene (slc5a6) leads to a reduction in presynaptic glycine release and also produces hyperekplexia (Harvey et al., 2008a).

Also $\alpha 3$ subunits are expressed in the spinal cord as heteromeric GlyRs. The $\alpha 3$ subunit distribution is restricted to the superficial layer of the adult dorsal horn of the spinal cord (Harvey et al., 2004), and the $\alpha 3$ subunit is involved in nociceptive processing by modulating the excitability of projection neurons that relay nociceptive input from peripheral afferents (Harvey et al., 2004, 2009; Zeilhofer, 2005). Prostaglandin E2, an important inflammatory mediator, induces protein kinase A-dependent phosphorylation at Ser346 of the a3 subunit to depress glycinergic synaptic transmission and facilitate inflammatory pain (Ahmadi et al., 2002; Harvey et al., 2004; Zeilhofer, 2005). Although the $\alpha 3$ knockout mice exhibited neither morphological abnormality nor neuro-motor phenotype, the prostaglandin E2 induced pain sensitization was abolished in the $\alpha 3$ knockout mice (Harvey et al., 2004). Hence the $\alpha 3$ subunit may therefore be a promising target for the regulation of inflammatory pain. In fact, cannabinoids that potentiate $\alpha 3$ subunit exhibited analgesic effect to chronic inflammatory pain without psychoactive side effect (Xiong et al., 2012). The $\alpha 3$ phosphorylation induced conformational change specifically on glycine binding site of the $\alpha 3$ subunit, because the serine residues is not conserved at the equivalent position of the $\alpha 1$ subunit (Harvey et al., 2004; Han et al., 2013). The specific conformational change may be a help to develop other type specific drugs potentiating the phosphorylated $\alpha 3$ subunit. Thus, the glycinergic synaptic transmission in spinal cord is mediated by the $\alpha 1 \beta$ and $\alpha 3 \beta$ heteromeric receptor, and synaptic transmission is an attractive for the development effective remedies. In addition to the pain regulation in spinal cord, changes in the activity of hippocampal $\alpha 3$ subunit are also associated with temporal lobe epilepsy (Eichler et al., 2008; Legendre et al., 2009; Winkelmann et al., 2014).

The $\alpha 2$ subunit mRNA encoded by GLRA2 gene is predominantly expressed in the developing spinal cord, and then the $\alpha 2$ subunit is largely replaced by the $\alpha 1$ subunit in this regions within 2 weeks after birth in mice (Kuhse et al., 1990; Malosio et al., 1991; Watanabe and Akagi, 1995; Singer et al., 1998; Liu and Wong-Riley, 2013). Functional $\alpha 2$ homomeric GlyRs also found in embryonic immature cortex neurons (Flint et al., 1998; YoungPearse et al., 2006). Although a previous study using $\alpha 2$ knockout mice showed no morphological or molecular alterations in nervous system development (Young-Pearse et al., 2006), recent analysis in newly established $\alpha 2$ knockout mice indicated that the $\alpha 2$ subunit contributes to several neural development process, such as tangential migration in developing cortex (Avila et al., 2013), cerebral cortical neurogenesis (Avila et al., 2014), morphogenesis and synaptogenesis of somatosensory cortical neuron (Morelli et al., 2016). The importance of $\alpha 2$ subunit in development and maturation of brain was also underscored by the recent identification of a micro-deletion and two mutations in GLRA2 gene from patients with autism spectrum disorder (Pinto et al., 2010; Pilorge et al., 2015).

After the developmental switching in the spinal cord, $\alpha 2$ and a3 subunits are still expressed as the predominant subunits in some regions of adult brain such as hippocampus and frontal cortex; in these regions the GlyRs contribute to regulation of neural excitability and synaptic plasticity (Chattipakorn and McMahon, 2002; Song et al., 2006; Zhang et al., 2006, 2008; Eichler et al., 2009; Kubota et al., 2010; Aroeira et al., 2011; Jonsson et al., 2012). GlyR $\beta$ subunit mRNA was abundantly detected throughout the embryonic and adult brain, from olfactory bulb to spinal cord (Fujita et al., 1991; Malosio et al., 1991). However, a recent immunohistochemical study using a novel monoclonal antibody to the GlyR $\beta$ subunit exhibited distinctive punctate staining of the $\beta$ subunit at synaptic sites only in spinal cord, brainstem, midbrain, olfactory bulb, and retina of adult mice (Weltzien et al., 2012). In contrast to these regions, only weak diffuse immunostaining signals were detected in the hypothalamus, the cerebellum, the hippocampus and the neocortex of adult mice (Weltzien et al., 2012). These observations suggest that most of GlyRs in adult brain are extrasynaptic homopentamer, as presented in previous studies about hippocampal GlyR (Chattipakorn and McMahon, 2002; Zhang et al., 2008; Aroeira et al., 2011). It has been suggested 
that the tonic inhibition by the neocortex GlyRs have antiepileptic effect (Chattipakorn and McMahon, 2003; Kirchner et al., 2003; Zhang et al., 2008; Shen et al., 2015). Epilepsy upregulated the expression of high-affinity GlyR through RNA editing in GlyR mRNA; this high-affinity GlyR may facilitate tonic inhibition to suppress the epileptic activity (Eichler et al., 2008).

In other region of adult brain, GlyRs are considered to participate in drug addiction. Studies using rodent models have revealed that some of the cortex GlyRs are involved in the behavioral effect of ethanol, such as a motor incoordination or a hypnosis (Quinlan et al., 2002; Ye et al., 2009; Blednov et al., 2012; McCracken et al., 2013a,b; Aguayo et al., 2014), and in the ethanol preference (Blednov et al., 2015). Ethanol increases extracellular dopamine levels in nucleus accumbens of the brain reward system through enhancement of the accumbal GlyR activity (Molander and Söderpalm, 2005; Molander et al., 2005; Maguire et al., 2014). The accumbal GlyRs are also involved in the dopamine-elevating effects of tetrahydrocannabinol and nicotine in the nucleus accumbens (Jonsson et al., 2014). Since dopamine elevation is a basis of drug addiction, the accumbal GlyR could be therapeutic targets of the addiction of ethanol or nicotine.

In addition to the expression within the brain, immunolabeling studies have demonstrated that all $\alpha$ subunits are also expressed in retina, especially in inner plexiform layer (IPL), with subunit -specific expression patterns (Sassoè-Pognetto et al., 1994; Haverkamp et al., 2003, 2004; Jusuf et al., 2005; Heinze et al., 2007; Weiss et al., 2008; Zhang et al., 2014), suggesting that different GlyR $\alpha$ subunits may be involved in different levels of visual processing (Wässle et al., 2009). Monoclonal antibody against the GlyR $\beta$ subunit revealed that the $\beta$ subunits were almost completely colocalized with GlyR $\alpha 1-3$ subunits and gephyrin in the IPL of mouse retina, however, GlyR $\alpha 4$ subunit did not show the highly colocalization with the $\beta$ subunits (Weltzien et al., 2012). Thus, most of the retinal GlyR are $\alpha \beta$ heteromeric receptor. The physiological role of these glycinergic synapses have been investigated by pharmacological and genetic approaches. For example, strychnine, a specific GlyR blocker, mediated blockade of glycinergic feedback pathway that from neuron in IPL to photoreceptor cell reduced the amplitudes of light-evoked response in both ON and OFF bipolar cells, indicating that the feedback pathway regulates signal propagation in the distal retina (Jiang et al., 2014). Genetic manipulations of GlyR $\alpha$ subunits in vivo have informed the significance of GlyR $\alpha$ subunit expression in the retina. Inhibitory glycinergic transmission between amacrine and bipolar cells of the retina is absent in GLRA1-deficient mice (Ivanova et al., 2006), and the frequency of spontaneous glycinergic input to A-type ganglion cells is also significantly reduced in the GLRA1-deficient retina (Majumdar et al., 2007). A study of GLRA2 knockout mice revealed that $\alpha 2$-containing GlyRs are involved in glycinergic input to group II wide-field amacrine cells (Majumdar et al., 2009). In the GLRA2-deficient retina, glycine-evoked currents are also reduced in MA-S5 and ON-starburst amacrine cells, suggesting that the $\alpha 2$ subunit is also involved in information processing by the amacrine cells. In GLRA3 deficient mice, spontaneous glycinergic currents are absent in AII amacrine cells (Weiss et al., 2008), additionally suggesting a role for the $\alpha 3$ subunit in these cells. In addition, $\alpha 2$ and $\alpha 3$ subunits enhance the excitatory center response of retinal receptive fields through modulation of local receptive field interactions (Nobles et al., 2012). Since the kinetics of glycinergic transmission differ according to $\alpha$ subunit type, signaling via different GlyRs may facilitate the complex regulation of retinal neuronal networks in visual processing.

\section{Mammalian Glycine Transporters}

Two glycine transporters have been identified in the mammalian CNS: glycine transporter 1 (GlyT1) and 2 (GlyT2). Both of these transporters belong to the $\mathrm{Na}^{+} / \mathrm{Cl}^{-}$dependent transporter family and mediate the uptake of glycine from the extracellular space into the cytosol (Eulenburg et al., 2005; Betz et al., 2006). GlyT1 is primarily expressed in glial cells throughout the CNS (Eulenburg et al., 2005; Betz et al., 2006). Glycinergic transporter 1 regulates glycine concentrations in the synaptic cleft of glycinergic synapses and glutamatergic synapses, where glycine acts as an essential co-agonist of NMDAR (Eulenburg et al., 2005; Betz et al., 2006). GlyT1 knockout mice display respiratory insufficiency as a result of elevated synaptic glycine and over-activation of GlyRs in the respiratory pathway (Gomeza et al., 2003a). Alternatively, GlyT2 is expressed in glycinergic neurons and mainly localizes to the presynaptic terminal. GlyT2 facilitates the uptake of glycine released into the presynaptic terminal in order to limit the extent of neurotransmission and allow the recycling of glycine for future synaptic transmission. Accordingly, GlyT2 knockout mice display attenuated glycinergic synaptic transmission (Gomeza et al., 2003b).

\section{GLYCINERGIC NEUROTRANSMISSION IN NON-MAMMALIAN SYSTEMS}

Many investigations to reveal the physiological role of glycinergic synapse have been conducted in the mammalian model animals or human; however, non-mammalian vertebrates have been used for investigation the physiological roles of glycinergic synapse in locomotive behaviors (Drapeau et al., 2002; Grillner, 2003; Korn and Faber, 2005; Roberts et al., 2008). Most teleosts have Mauthner cells (M-cells), which are paired large neurons found in their hindbrain (Eaton et al., 1977; Zottoli, 1977). The M-cell is activated by auditory input, and the M-cell firing triggers fast escape behaviors (Kohashi and Oda, 2008; Kohashi et al., 2012). Both excitatory (e.g., glutamatergic) and inhibitory (e.g., glycinergic and GABAergic) synapses are formed on dendrites and soma of the M-cell (Korn and Faber, 2005). In goldfish, glycinergic input to $\mathrm{M}$-cells was enhanced by tetanization of the auditory pathway (Korn et al., 1992) or repeated sound stimulation (Oda et al., 1998). Glycinergic synaptic transmission reduces $\mathrm{M}$-cell excitability by countering concurrent excitatory synaptic input (Korn and Faber, 2005; Curtin and Preuss, 2015). Thus, the plasticity of the glycinergic synapse has been shown to regulate auditory conditioning of the escape response (Oda et al., 1998). Recently, zebrafish (Danio rerio) have also been used as a model for investigating the physiological roles of glycinergic 
neurotransmission (Cui et al., 2005; Hirata et al., 2005; Downes and Granato, 2006; Rigo and Legendre, 2006; Mongeon et al., 2008). In this review, we will describe advances in both forward and reverse genetic approaches as well as visualization techniques that have proven helpful for the study of the glycinergic synapse in zebrafish.

\section{Zebrafish Glycine Receptors}

In total, zebrafish express five a subunits (glra1, glra2, glra3, glra $4 a$ and glra4b) and two $\beta$ subunits ( $g l r b a$ and glrbb) (Hirata et al., 2010). Four GlyR $\alpha$ subunits ( $\alpha Z 1, \alpha Z 2, \alpha Z 3$, and $\alpha Z 4$ ) and two $\beta$ subunits $(\beta a / \beta Z$ and and $\beta b)$ were initially reported in zebrafish (David-Watine et al., 1999; Imboden et al., 2001a,b,c; Hirata et al., 2005). Although $\alpha$ Z2 was originally thought to encode a GlyR $\alpha 2$ subunit (Imboden et al., 2001a), the gene was subsequently reclassified as a second $\alpha 4$ subunit in a more detailed phylogenetic analysis (Imboden et al., 2001b). Thus, $\alpha$ Z2 was designated glra4a. Phylogenetic analyses have suggested that $\alpha Z 1, \alpha Z 3$, and $\alpha Z 4$ subunits are orthologs of the mammalian $\alpha 1, \alpha 3$, and $\alpha 4$ GlyR subunits, respectively (Imboden et al., 2001b); thus, these subunits have been referred to as the zebrafish GlyR $\alpha 1$, GlyR $\alpha 3$, and GlyR $\alpha 4 b$. Of note, the existence of distinct orthologs of a mammalian gene is common in the zebrafish genome due to suspected whole genome duplication during fish evolution (Amores et al., 1998). The spatial expression of GlyR genes has been examined using in situ hybridization (Table 1). Although the spatial expression patterns of glra2 and glra3 remain to be determined, quantitative PCR analysis of developing zebrafish embryos (24-72 hpf) has revealed the temporal expression patterns for these genes: glra1, glra3, and glra4a were observed at $24 \mathrm{hpf}$, whereas glra2 expression was not induced until $32 \mathrm{hpf}$ (Ganser et al., 2013). Moreover, the expression levels of glra1, glra2, and glra $4 a$ were noted to steadily increase during development, while the expression of glra3 subsided after $48 \mathrm{hpf}$ (Ganser et al., 2013). Knock down experiments using antisense morpholino oligo (MO) have reported the specific involvement of glra4a in the differentiation of spinal interneurons (McDearmid et al., 2006).

\section{The Advantages of Zebrafish as a Vertebrate Model}

Zebrafish offer several advantages as a model for vertebrate development. First, zebrafish quickly reach sexual maturity (within 3 months), and the adult zebrafish lay 100-200 eggs twice a week, such that fertilized eggs are readily available throughout the year with a relatively low cost, because a large number of zebrafish can be maintained in smaller space compared to model mammals. Second, zebrafish embryos are optically transparent, and their development progresses rapidly at $28.5^{\circ} \mathrm{C}$ (Kimmel et al., 1995). These characteristics are helpful for developmental studies in vivo. Indeed, in vivo imaging of events such as synapse formation and subcellular CaMKII translocation has been achieved through the use of green fluorescent protein tagging in zebrafish embryos (Gleason et al., 2003; Niell et al., 2004). Moreover, the transparency of early zebrafish embryos has enabled the in vivo study and manipulation of neural activity (Douglass et al., 2008; Arrenberg et al., 2009; Zhu et al., 2009; Schoonheim et al., 2010; Muto et al., 2011). While the transparency of the zebrafish embryo is progressively diminished by the formation of melanophores after $24 \mathrm{hpf}, 1$-phenyl 2thiourea (PTU) is a widely used agent to prevent the pigment formation (Karlsson et al., 2001). Alternatively, because it is not feasible to grow zebrafish into adulthood in the presence of PTU, a pigment-deficient mutant known as casper is now available, and facilitates the in vivo visualization and manipulation of neural activity in adult zebrafish (White et al., 2008). Third, zebrafish are suitable for electrophysiological analyses. The activity of neurons and muscles can be recorded using standard patch-clamp and extracellular recording techniques during most stages of zebrafish development (Grunwald et al., 1988; Legendre and Korn, 1994, 1995; Ribera and Nüsslein-Volhard, 1998; Drapeau et al., 1999;

TABLE 1 | Spatial expression pattern of glycine receptor subunits

\begin{tabular}{|c|c|c|c|}
\hline Gene & Stage & Expressing tissue & Reference \\
\hline \multirow[t]{3}{*}{ glra1 } & $24 \mathrm{hpf}$ & $\begin{array}{l}\text { Telencephalon, posterior part of midbrain midbrain-hindbrain boundary reticular neurons } \\
\text { of hindbrain, spinal neurons, eye primordium }\end{array}$ & $\begin{array}{l}\text { Devignot et al., } 2003 \\
\text { Hirata et al., } 2005\end{array}$ \\
\hline & $48 \mathrm{hpf}$ & Spinal neurons & McDearmid et al., 2006 \\
\hline & 52 hpf & Telencephalon, Diencephalon, Midbrain, Hindbrain, Spinal cord & Devignot et al., 2003 \\
\hline glra2 & & Remain to be determined & \\
\hline glra3 & & Remain to be determined & \\
\hline \multirow[t]{2}{*}{ glra4a } & $24 \mathrm{hpf}$ & $\begin{array}{l}\text { Subset of cells in the telencephalon, rhombic lip, midbrain-hindbrain boundary region, } \\
\text { reticular neurons of hindbrain, spinal neuron, somite }\end{array}$ & $\begin{array}{l}\text { Imboden et al., } 2001 \mathrm{~b} \\
\text { McDearmid et al., } 2006\end{array}$ \\
\hline & $52 \mathrm{hpf}$ & Olfactory pit, midbrain, reticular neurons of hindbrain, somite & Imboden et al., 2001b \\
\hline \multirow[t]{2}{*}{ glra4b } & $24 \mathrm{hpf}$ & Rhombensephalic lip, midbrain hindbrain boundary region & Imboden et al., 2001b \\
\hline & $52 \mathrm{hpf}$ & Ganglion cell layer of retina & Imboden et al., 2001b; Hensley et al., 2011 \\
\hline glrba & & Remain to be determined & \\
\hline glrbb & $24 \mathrm{hpf}$ & Reticular neurons of hindbrain, spinal neuron & Hirata et al., 2005 \\
\hline
\end{tabular}


Saint-Amant and Drapeau, 2001; Sidi et al., 2003; Higashijima et al., 2004; Kimura et al., 2006; Fetcho, 2007; McLean et al., 2007; Tanimoto et al., 2009). Finally, the high-efficient mutagenesis and transgenesis are available in zebrafish, as discussed in a later section of this review.

In addition to the usefulness in developmental study, zebrafish is also valuable model for high-throughput screening of novel drugs (Peterson et al., 2000; Goldsmith, 2004; Love et al., 2004). The high-throughput screening using mutant zebrafish model of human disease have identified novel compound that potentially ameliorate the phenotype associated with the mutation (Peterson et al., 2004; Cao et al., 2009; Paik et al., 2010; Kawahara et al., 2011; Peal et al., 2011; Baraban et al., 2013).

\section{The Development of Locomotive Behavior}

Zebrafish exhibit three distinct behaviors during embryogenesis: spontaneous coiling, touch-evoked escape contractions, and swimming. Spontaneous coiling appears after $17 \mathrm{hpf}$, and consists of side-to-side alternating contractions of the axial muscles (Saint-Amant and Drapeau, 1998; Downes and Granato, 2006; Pietri et al., 2009). The frequency of spontaneous coiling reaches a peak of $0.3-1 \mathrm{~Hz}$ at $19 \mathrm{hpf}$ and gradually declines to less than $0.1 \mathrm{~Hz}$ by $26 \mathrm{hpf}$. After $21 \mathrm{hpf}$, zebrafish embryos respond to tactile stimuli with escape contractions that typically consists of two-to-three rapid, alternating contractions of the axial muscles (Saint-Amant and Drapeau, 1998; Hirata et al., 2005). By 28 hpf, tactile stimuli initiate swimming (Saint-Amant and Drapeau, 1998). The frequency of swimming contractions reaches $30 \mathrm{~Hz}$ at $36 \mathrm{hpf}$, which is comparable to the frequency of tail contraction in adult zebrafish (Buss and Drapeau, 2001). Thus, the neural network regulating swimming is functionally matured within 1.5 days of development. Interestingly, head-removed embryos transected at somites 5-7 are capable of responding to touch with an initial tail flip, although swimming fails to follow in most cases (Downes and Granato, 2006). Indeed, detailed observations suggest that the spinal cord can initiate touch responses, while supraspinal input is necessary for swimming. The spinal cord region located between somites 5-10 somite appears to be responsible for spontaneous coiling (Pietri et al., 2009). Given this knowledge, a variety of in vivo and ex vivo manipulations are possible in zebrafish.

\section{Mutagenesis and Transgenesis in Zebrafish}

Mutagenesis for the forward genetic screening of zebrafish mutants was first established in the early 1990's (Mullins et al., 1994), and two large-scale $N$-ethyl- $N$-nitrourea (ENU)-based mutagenesis projects were completed in Tübingen, Germany and Boston, USA by 1996. These screens identified more than 4,000 mutants, including motility defective mutants, caused by the dysfunction of glycinergic neurotransmission.

Additionally, more comprehensive ENU-based mutagenesis project named "Zebrafish Mutation Project (ZMP)" was launched in 2011. ZMP identified potentially disruptive mutations in more than $38 \%$ of all known zebrafish protein-coding genes (Kettleborough et al., 2013). The forward genetic approach provides an opportunity to identify novel genes participating in the investigating subject. The growing list of disruptive mutated alleles will be a valuable resource both for fundamental and clinical research to reveal the interested gene function.

On the other hand, reverse genetic approaches has also been applied to zebrafish biology. Targeting-induced local lesions in genomes (TILLING) has been introduced to zebrafish as the first available reverse genetics method (Wienholds et al., 2002). TILLING is a combinational method of chemical-induced mutagenesis and high-throughput screening; accordingly, TILLING can generate not only loss of function mutations, but also unexpected mutations due to non-directional missense mutagenesis (Wienholds et al., 2002, 2003; Moens et al., 2008). However, TILLING is time-consuming and less effective for intron-rich genes due to a decreased chance of obtaining null or hypomorphic alleles (Stemple, 2004). Subsequently, Zinc finger nucleases (ZFNs) (Doyon et al., 2008; Meng et al., 2008; Foley et al., 2009; Sander et al., 2011a) and transcription activator-like effector nucleases (TALEN) (Sander et al., 2011b; Bedell et al., 2012; Cade et al., 2012; Dahlem et al., 2012) were introduced to zebrafish genetics as targeted mutagenesis methods. ZFNs utilize an array of zinc finger DNA-binding motifs that bind to specific DNA triplet sequences (Urnov et al., 2005; Carroll, 2011). However, the exact DNA binding specificity of ZFNs has not been completely resolved (Carroll, 2011) and thus each ZFN construct requires careful design and screening of its target DNA-binding zinc finger motifs. Alternatively, TALEN DNA binding specificity is more predictable (Miller et al., 2011). The DNA-binding motif of TALEN is composed of repeated modules, where each module independently binds to a specific single nucleotide through repeat variable di-residues in a 1:1 manner. Thus, each module is a functional unit for the recognition of DNA sequences (Boch et al., 2009; Moscou and Bogdanove, 2009). This simple rule of nucleotide recognition has made TALEN more popular than ZFN for zebrafish genetics.

More recently, the clustered regularly interspaced palindromic repeats/CRISPR-associated 9 (CRISPER/Cas9) method was applied to zebrafish as a surprisingly simple and effective method. CRISPR and Cas are involved in bacterial adaptive immunity against the invasion of foreign nucleic acids derived from exogenous plasmids or bacteriophages (Barrangou et al., 2007; Garneau et al., 2010; Horvath and Barrangou, 2010). In type II CRISPR/Cas systems, Cas9 nuclease is guided to the target site by two RNA molecules, tracrRNA and crRNA. Alternatively, the use of a single chimeric guide RNA, generated by fusing the $3^{\prime}$ end of a crRNA to the $5^{\prime}$ end of a tracrRNA, has been used to guide Cas9 to its target site (Jinek et al., 2012). Thus, instead of the need to design a DNA binding domain consisting of several 10-100s amino acids as in the case of ZFN and TALEN, a single small guide RNA can be used in CRISPR/Cas9. Codon-optimized Cas9 with guide RNA efficiently induces target sequence-specific genome modification in humans and mammals (Cong et al., 2013; Li D. et al., 2013; Li W. et al., 2013; Mali et al., 2013). In zebrafish, CRISPR/Cas9 produces targeted gene 
lesion with a similar efficiency to that of TALENs (Chang et al., 2013; Hwang et al., 2013). Furthermore, the mutagenesis efficiency was improved with zebrafish codon optimized Cas 9 (Jao et al., 2013; Liu et al., 2014). The off-target effects of the CRISPR/Cas9 method are reported to be quite limited (Chang et al., 2013; Hruscha et al., 2013; Hwang et al., 2013; Jao et al., 2013), although some studies in cultured cells have reported high off-target mutagenesis (Fu et al., 2013; Hsu et al., 2013). This complication can be resolved through back-crossing with wildtype zebrafish. CRISPE/Cas9 system is able to introduce not only an in-del mutation leading to gene knockout, but also exogenouse coding DNA in site specific manner (Auer et al., 2014; Kimura et al., 2014; Hisano et al., 2015). The site specific insertion allows researchers to substitute any nucleotides or amino acids, or to tagging any protein with fluorescent protein or epitope tag.

Other than the knockout technologies, MO injection into fertilized eggs has been widely used as gene knockdown method (Nasevicius and Ekker, 2000). However, in some cases MO-induced phenotypes (morphant) were not observed to correspond with equivalent mutants generated by ZFN and TALEN (Kok et al., 2015). Phenotypic discrepancies between morphants and mutants may be due to the off-target effects of MO (Kok et al., 2015). Alternatively, genetic compensation induced by deleterious mutation has also been reported as a cause of phenotype variation between morphants and mutants, as compensatory gene upregulation is not typically observed in MO-injected embryos (Rossi et al., 2015). Regardless of the cause of phenotypic discrepancy, antisense MOs should be used with meticulous care, and consider dose dependency as well as the implementation of proper positive and negative controls.

Transposon or retroviral methods have also been used to generate transgenic zebrafish (Davidson et al., 2003; Kawakami et al., 2004; Ellingsen et al., 2005; Villefranc et al., 2007; Asakawa et al., 2008) with improved efficiency (Davidson et al., 2003; Kawakami et al., 2004; Ellingsen et al., 2005; Sivasubbu et al., 2006; Villefranc et al., 2007). This increased efficiency has facilitated the use of the yeast GAL4/UAS system (Scheer and Campos-Ortega, 1999; Inbal et al., 2006; Scott et al., 2007; Asakawa et al., 2008; Halpern et al., 2008). GAL4, a yeast transcriptional activator, is capable of binding UAS sequences and driving the expression of downstream genes (Brand and Perrimon, 1993; Asakawa and Kawakami, 2008). Thus, a gene of interest can be expressed in any tissue by crossing UAS transgenic zebrafish with tissue-specific GAL4 driver transgenic zebrafish. Recently, various GAL4 driver transgenic zebrafish have been established using the Tol2 transposon-mediated enhancer trap method (Asakawa and Kawakami, 2008; Kawakami et al., 2010). In fact, the GAL4/UAS system has proven to have great utility for in vivo imaging and the manipulation of neural activity in zebrafish (Douglass et al., 2008; Arrenberg et al., 2009; Zhu et al., 2009; Schoonheim et al., 2010; Muto et al., 2011, 2013). However, GAL4/UAS systems also have a disadvantage. It has been reported that the methylation at $\mathrm{CpG}$ nucleotides in the UAS sequences could silence the transgene expression in zebrafish that is offspring of the founder (Goll et al., 2009; Akitake et al., 2011; Pang et al., 2015). Although tryptophan repressor (TrpR) and its upstream activation sequence (tUAS) was proposed as an alternative gene expression system to overcome the silencing effect of Gal4/UAS, TrpR/tUAS system gave toxic effect to developing zebrafish may be due to strong transcriptional activity or toxic effect of TrpR protein (Suli et al., 2014). Four distinct Gal4 binding sites that placed in tandem ( $4 \mathrm{x} \mathrm{nr}$ UAS) drove high levels of reporter expression with significantly less susceptible to the methylation compare to fourteen tandem copies of UAS (Akitake et al., 2011). Therefore, the fewere non-repetitive UAS sequence could be useful to circumvent the silencing by the methylation.

\section{The Non-invasive Imaging of Neuronal Excitability}

Inhibitory glycinergic and GABAergic synaptic inputs critically regulate neuronal excitability. Electrophysiological techniques are available for the monitoring of single neuron excitability through membrane potential and synaptic current recordings; however, it is difficult to investigate network excitability using this approach. An alternative approach is the monitoring of $\mathrm{Ca}^{2+}$ transients as a surrogate of excitability. To this end, genetically encoded calcium indicators have been used for $\mathrm{Ca}^{2+}$ imaging in zebrafish (Muto et al., 2011). GCaMP, the most widely used genetically encoded calcium indicator, is a fusion protein of circularly permuted EGFP, calmodulin, and calmodulininteracting M13 peptide (Baird et al., 1999; Nakai et al., 2001). Although the fluorescence intensity of circularly permuted EGFP is very low, conformational changes induced by $\mathrm{Ca}^{2+}$ binding to calmodulin lead to the enhancement of fluorescence intensity and improved detection. The sensitivity of this method has been improved by the generation of GCaMP variants, which are now available for research use (Ohkura et al., 2005; Tallini et al., 2006; Tian et al., 2009; Akerboom et al., 2012; Chen et al., 2013; Muto et al., 2013). Muto et al. (2011) have successfully used this technique to visualize the alternating activation of spinal motor neurons during spontaneous coiling, and neural activity in the optic tectum during prey capture behavior (Muto et al., 2013).

\section{ZEBRAFISH MOTILITY DEFECT MUTANTS}

In the Tübingen screen, 166 mutants showing motility defects between 48 and $60 \mathrm{hpf}$ were identified (Granato et al., 1996). Among them, 63 mutants were assumed to be muscle-defective based on the simple observation of actin-myosin organization (birefringence intensity) under polarized light (Felsenfeld et al., 1990). Mutations in dystrophin, laminin, titin, Hsp90 and the cognate co-chaperone Unc45b were identified in this manner (Bassett et al., 2003; Etard et al., 2007; Hall et al., 2007; Steffen et al., 2007; Hawkins et al., 2008; Guyon et al., 2009). The other 103 mutants with normal muscle structure were divided into two groups: locomotion abnormal and reduced motility (Granato et al., 1996), and assumed to have impairments 
in the nervous system, neuromuscular junction (NMJ), or muscular functional components. Electrophysiological analyses have been useful in delineating the exact cause of each abnormality. For example, electrophysiological recordings from the accordion (acc) mutant, a locomotion abnormal mutant, revealed normal neuronal outputs and thus implicated deficits in the functional components of the muscle (Hirata et al., 2004). In the atp2a1 mutant, it was determined that the simultaneous contraction of the bilateral trunk muscles results from the impaired clearance of cytosolic $\mathrm{Ca}^{2+}$ by the sarcoplasmic reticulum $\mathrm{Ca}^{2+}$-ATPase SERCA1 (Gleason et al., 2004; Hirata et al., 2004). Several other muscle mutants (relaxed, relatively relaxed) have exhibited defects in excitation-contraction coupling (Schredelseker et al., 2005, 2009; Zhou et al., 2006; Hirata et al., 2007).

Six abnormal locomotive mutants (bandoneon, ziehharmonika, bajan, diwanka, quetschkommode, and expander) were previously compared with the acc mutant (Granato et al., 1996). In contrast to acc, electrophysiological recordings from the bandoneon (beo) mutant showed aberrant, arrhythmic fluctuations in response to tactile stimulation, indicating a defect in CNS output (Hirata et al., 2005). As will be described in detail, a molecular genetic study revealed that alteration of the glrbb gene is responsible for the beo mutant, and thus beo exhibits defects in glycinergic synaptic transmission (Hirata et al., 2005). Of note, beo is the only known acc subgroup mutant with dysfunctional glycinergic transmission (Table 2).

In addition to beo, the shocked (sho) mutant also shows reduced mobility due to a defect in glycinergic synaptic transmission. The sho gene encodes the glycine transporter GlyT1 (Cui et al., 2005; Mongeon et al., 2008). Based on its function, the loss-of-function mutation of GlyT1 should increase the availability of extracellular glycine in the CNS. Overactivation of the glycinergic synapse by elevated extracellular glycine can suppress the neural network responsible for motility, and therefore result in a phenotype of reduced mobility. Of note, strychnine, a specific inhibitor of GlyR, partially restores normal neuronal activity in sho mutants (Cui et al., 2005). Other

\section{TABLE 2 | Accordion mutants.}

\begin{tabular}{|c|c|c|c|c|c|}
\hline Mutant & Responsible gene & Alleles & Substitutions & Cause of defective behavior & References \\
\hline $\begin{array}{l}\text { accordion } \\
\text { acc }\end{array}$ & $\begin{array}{l}\text { Sarcoplasmic reticulum } \mathrm{Ca}^{2+} \\
\text { ATPase SERCA1 gene (atp2a1) } \\
\text { on chromosome } 3\end{array}$ & $\begin{array}{l}\text { dta5 } \\
\text { mi25i } \\
\text { mi289a } \\
\text { tc249a } \\
\text { ti284a } \\
\text { tm286 } \\
\text { tn218b } \\
\text { tp72x } \\
\text { tq206 } \\
\text { ty20 }\end{array}$ & $\begin{array}{l}\text { G598V } \\
\text { I97N } \\
\text { T848I } \\
\text { Unknown } \\
\text { Unknown } \\
\text { Unknown } \\
\text { Unknown } \\
\text { Unknown } \\
\text { S766F } \\
\text { Unknown }\end{array}$ & $\begin{array}{l}\text { Impaired clearance of cytosolic } \\
\mathrm{Ca}^{2+} \text { in muscle cells. }\end{array}$ & $\begin{array}{l}\text { Granato et al., 1996; } \\
\text { Gleason et al., 2004; Hirata } \\
\text { et al., 2004; Masino and } \\
\text { Fetcho, 2005; Olson et al., } \\
2010\end{array}$ \\
\hline $\begin{array}{l}\text { bajan } \\
\text { baj }\end{array}$ & $\begin{array}{l}\text { Choline acetyltransferase gene } \\
\text { (chat) on chromosome } 13\end{array}$ & tf247 & $\begin{array}{l}\text { IVS2- } \\
2 \mathrm{~A}>\mathrm{C}\end{array}$ & $\begin{array}{l}\text { Attenuated transmission at } \\
\text { neuromuscular junction }\end{array}$ & $\begin{array}{l}\text { Granato et al., 1996; Wang } \\
\text { et al., } 2008\end{array}$ \\
\hline $\begin{array}{l}\text { bandoneon } \\
\text { beo }\end{array}$ & $\begin{array}{l}\text { GlyR } \beta \text { subunit gene (g/rbb) on } \\
\text { chromosome } 14\end{array}$ & $\begin{array}{l}\text { tp221 } \\
\text { tw38f } \\
\text { ta86d } \\
\text { ta92 } \\
\text { tm115 } \\
\text { tf242 } \\
\text { tu230 } \\
\text { mi106a }\end{array}$ & $\begin{array}{l}\text { Y79X } \\
\text { L255R } \\
\text { Y79X } \\
\text { K343X } \\
\text { Q87X } \\
\text { Y79D } \\
\text { Allele lost } \\
\text { R275H }\end{array}$ & $\begin{array}{l}\text { Dysfunction of glycinergic } \\
\text { synaptic transmission on spinal } \\
\text { motor neurons due to defect in } \\
\text { clustering formation of glycine } \\
\text { receptor at synapses }\end{array}$ & $\begin{array}{l}\text { Granato et al., 1996; Hirata } \\
\text { et al., 2005; Ganser et al., } \\
2013\end{array}$ \\
\hline $\begin{array}{l}\text { diwanka } \\
\text { diw }\end{array}$ & $\begin{array}{l}\text { Procollagen lysin } 2 \text { - } \\
\text { oxoglutarate } 5 \text {-dioxygenase } 3 \\
\text { gene (plod3) on } \\
\text { chromosome } 23\end{array}$ & $\begin{array}{l}\text { ts286 } \\
\text { tv205a } \\
\text { tz290 }\end{array}$ & $\begin{array}{l}\text { Q608X } \\
\text { IVS4- } \\
2 A>G \\
\text { W447X }\end{array}$ & $\begin{array}{l}\text { Defect in primary motoneuron } \\
\text { projection. } \\
\text { All primary motor axons fail to } \\
\text { exit the spinal cord }\end{array}$ & $\begin{array}{l}\text { Granato et al., 1996; Zeller } \\
\text { and Granato, 1999; Zeller } \\
\text { et al., 2002; Schneider and } \\
\text { Granato, } 2006\end{array}$ \\
\hline $\begin{array}{l}\text { expander } \\
\text { exp }\end{array}$ & Unknown & tu12 & Unknown & Unknown & Granato et al., 1996 \\
\hline $\begin{array}{l}\text { quetschkommode } \\
\text { que }\end{array}$ & $\begin{array}{l}\text { Dihydrolipoamide branched } \\
\text { chain transacylase E2 }(d b t) \\
\text { gene on chromosome } 22\end{array}$ & $\mathrm{ti2} 274$ & IVS6 + 1G > A & $\begin{array}{l}\text { Abnormal output from CNS. } \\
\text { The abnormality may be result } \\
\text { of decrease in neurotransmitter } \\
\text { glutamate level within CNS due } \\
\text { to dysfunction of amino acid } \\
\text { metabolism }\end{array}$ & $\begin{array}{l}\text { Granato et al., 1996; } \\
\text { Friedrich et al., } 2012\end{array}$ \\
\hline $\begin{array}{l}\text { ziehharmonika } \\
\text { zim }\end{array}$ & $\begin{array}{l}\text { Acetylcholine-esterase gene } \\
\text { (ache) on chromosome } 7\end{array}$ & $\begin{array}{l}\text { sb55 } \\
\text { tf222a } \\
\text { tm205 } \\
\text { tm206 }\end{array}$ & $\begin{array}{l}\text { S226N } \\
\text { G198R } \\
\text { Y139X } \\
\text { Allele lost }\end{array}$ & $\begin{array}{l}\text { Reduction of acetylcholine } \\
\text { receptor clustering at } \\
\text { neuromuscular junction }\end{array}$ & $\begin{array}{l}\text { Granato et al., 1996; Behra } \\
\text { et al., 2002; Downes and } \\
\text { Granato, } 2004\end{array}$ \\
\hline
\end{tabular}


mutants with reduced mobility have gene mutations unrelated to glycinergic transmission (Table 3).

\section{Defective GlyR Clustering in the bandoneon Mutant}

The tubingen mutant screen identified seven mutant alleles (tp221 = Y79X, tw38f $=$ L255R, ta86d $=$ Y79X, ta92 $=$ K343X, tm115 = Q87X, tf242 = Y79D, and tu230 = lost) of glrbb (Granato et al., 1996; Ganser et al., 2013). In addition, we have isolated an eighth allele $(\operatorname{mi106a}=\mathrm{R} 275 \mathrm{H})$ in a previous mutagenesis screen (Hirata et al., 2005). These zebrafish glrbb mutants were named bandoneon after the South American accordion-like instrument. Phenotypically, the bandoneon mutations show simultaneous contraction of both axial muscles instead of alternating in response to touch stimuli; therefore, the mutant body length is shortened by tactile stimuli, similar to the movement of an accordion (Hirata et al., 2005). Since axial muscle contractions are controlled by the reciprocal inhibition of the left and right sides of the spinal cord, inhibitory synaptic transmission is required to produce alternating contractions for swimming (Grillner, 2003; Roberts et al., 2008). As abovementioned, GlyR clustering at synaptic

TABLE 3 | Mutants with reduced locomotion.

\begin{tabular}{|c|c|c|c|c|c|}
\hline Mutant & Responsible gene & Alleles & Substitutions & Cause of defective behavior & References \\
\hline $\begin{array}{l}\text { sofa potato } \\
\text { sop }\end{array}$ & $\begin{array}{l}\text { Acetylcholine receptor } \delta \text { subunit } \\
\text { gene on chromosome } 24\end{array}$ & $\begin{array}{l}\text { tj19d } \\
\text { ts29 } \\
\text { tf207c }\end{array}$ & $\begin{array}{l}\text { L28P } \\
\text { Unknown } \\
\text { Unknown }\end{array}$ & $\begin{array}{l}\text { Loss of neuromuscular } \\
\text { transmission due to defect in } \\
\text { acetylcholine receptor clustering }\end{array}$ & $\begin{array}{l}\text { Granato et al., 1996; Ono et al., } \\
\text { 2001, } 2004\end{array}$ \\
\hline $\begin{array}{l}\text { relaxed } \\
\text { red }\end{array}$ & $\begin{array}{l}\text { Dihydropyridine receptor } \beta_{1 a} \\
\text { subunit gene }(C A C N B 1) \text { on } \\
\text { chromosome } 3\end{array}$ & $\begin{array}{l}\text { ts } 25 \\
\text { mi90 }\end{array}$ & $\begin{array}{l}\text { W451X } \\
\text { Y283X }\end{array}$ & $\begin{array}{l}\text { Defect in excitation-contraction } \\
\text { coupling }\end{array}$ & $\begin{array}{l}\text { Granato et al., 1996; Zhou } \\
\text { et al., 2006; Schredelseker } \\
\text { et al., } 2009\end{array}$ \\
\hline $\begin{array}{l}\text { nicotinic } \\
\text { receptor } \\
\text { nic }\end{array}$ & $\begin{array}{l}\text { Acetylcholine receptor } \alpha \text { subunit } \\
\text { gene on chromosome } 6\end{array}$ & tk48d & Unknown & $\begin{array}{l}\text { Loss of neuromuscular } \\
\text { transmission due to defect in } \\
\text { acetylcholine receptor clustering }\end{array}$ & Granato et al., 1996 \\
\hline $\begin{array}{l}\text { heart attack } \\
\text { hat }\end{array}$ & Unknown & te313 & Unknown & Unknown & Granato et al., 1996 \\
\hline $\begin{array}{l}\text { herzschlag } \\
\text { hel }\end{array}$ & Titin gene (ttna) on chromosome 9 & $\operatorname{tg} 287$ & Unknown & Unknown & $\begin{array}{l}\text { Granato et al., 1996; Myhre } \\
\text { et al., } 2014\end{array}$ \\
\hline $\begin{array}{l}\text { unplugged } \\
\text { unp }\end{array}$ & $\begin{array}{l}\text { Muscle specific receptor tyrosine } \\
\text { kinase gene on chromosome } 10\end{array}$ & te314b & Unknown & $\begin{array}{l}\text { Defect in initial outgrowth of motor } \\
\text { axons }\end{array}$ & $\begin{array}{l}\text { Granato et al., 1996; Lefebvre } \\
\text { et al., 2007; Jing et al., } 2009\end{array}$ \\
\hline $\begin{array}{l}\text { shocked } \\
\text { sho }\end{array}$ & $\begin{array}{l}\text { Glycine transporter } 1 \text { gene (s/c6a9) } \\
\text { on chromosome } 2\end{array}$ & $\begin{array}{l}\text { ta51e } \\
\text { te301 } \\
\text { ta229g }\end{array}$ & $\begin{array}{l}\text { Unknown } \\
\text { C893Y } \\
\text { G81D }\end{array}$ & $\begin{array}{l}\text { Over-activation of glycinergic } \\
\text { synapse by elevated extracellular } \\
\text { glycine level }\end{array}$ & $\begin{array}{l}\text { Granato et al., 1996; Luna } \\
\text { et al., 2004; Cui et al., 2005; } \\
\text { Mongeon et al., } 2008\end{array}$ \\
\hline $\begin{array}{l}\text { twitch once } \\
\text { two }\end{array}$ & $\begin{array}{l}\text { Acetylcholine receptor clustering } \\
\text { factor rapsyn gene (rapsn) on } \\
\text { chromosome } 18\end{array}$ & $\begin{array}{l}\text { th26e } \\
\text { tm335 } \\
\text { tq265b }\end{array}$ & $\begin{array}{l}\text { G130E } \\
\text { Unknown } \\
\text { Unknown }\end{array}$ & $\begin{array}{l}\text { Loss of neuromuscular } \\
\text { transmission due to defect in } \\
\text { acetylcholine receptor clustering }\end{array}$ & $\begin{array}{l}\text { Granato et al., 1996; Ono et al., } \\
\text { 2002, } 2004\end{array}$ \\
\hline $\begin{array}{l}\text { alligator } \\
\text { ali }\end{array}$ & $\begin{array}{l}\text { RING finger protein } 121 \text { gene } \\
\text { (rnf121) on chromosome } 21\end{array}$ & $\begin{array}{l}\operatorname{tm} 342 \\
\text { mi500 }\end{array}$ & $\begin{array}{l}\text { L39X } \\
\text { V232A }\end{array}$ & $\begin{array}{l}\text { Defect in the excitability of sensory } \\
\text { Rohon-Beard neurons }\end{array}$ & $\begin{array}{l}\text { Granato et al., 1996; Ogino } \\
\text { et al., } 2015\end{array}$ \\
\hline $\begin{array}{l}\text { fakir } \\
\text { far }\end{array}$ & $\begin{array}{l}\alpha \text { subunit of voltage-gated calcium } \\
\text { channel } 2.1 \mathrm{~b} \text { gene (CACNA1Ab)on } \\
\text { chromosome } 11\end{array}$ & $\operatorname{tm} 154$ & L356V & $\begin{array}{l}\text { Reduced synaptic transmission } \\
\text { between Rohon-Beard neuron and } \\
\text { interneuron }\end{array}$ & $\begin{array}{l}\text { Granato et al., 1996; Low et al., } \\
2012\end{array}$ \\
\hline $\begin{array}{l}\text { macho } \\
\text { mao }\end{array}$ & Pigk gene (pigk) on chromosome 2 & $\mathrm{tt} 261$ & M1T & $\begin{array}{l}\text { Defect in the excitability of sensory } \\
\text { Rohon-Beard neurons }\end{array}$ & $\begin{array}{l}\text { Granato et al., 1996; Carmean } \\
\text { et al., } 2015\end{array}$ \\
\hline $\begin{array}{l}\text { steifftier } \\
\text { ste }\end{array}$ & Unknown & $\mathrm{tf} 220$ & Unknown & $\begin{array}{l}\text { Defect in the excitability of sensory } \\
\text { Rohon-Beard neurons }\end{array}$ & Granato et al., 1996 \\
\hline $\begin{array}{l}\text { crocodile } \\
\text { cro }\end{array}$ & Unknown & $\begin{array}{l}\text { tw212d } \\
\text { m148 } \\
\text { s3556 }\end{array}$ & $\begin{array}{l}\text { Unknown } \\
\text { Unknown } \\
\text { Unknown }\end{array}$ & Unknown & Granato et al., 1996 \\
\hline $\begin{array}{l}\text { schlaffi } \\
\text { sla }\end{array}$ & Unknown & $\begin{array}{l}\operatorname{ty} 112 \\
\text { th239 } \\
\operatorname{tg} 230\end{array}$ & $\begin{array}{l}\text { Unknown } \\
\text { Unknown } \\
\text { Unknown }\end{array}$ & Unknown & Granato et al., 1996 \\
\hline $\begin{array}{l}\text { slumber } \\
\text { slm }\end{array}$ & Unknown & $\begin{array}{l}\text { tt208 } \\
\text { tm221 } \\
\text { tm132c }\end{array}$ & $\begin{array}{l}\text { Unknown } \\
\text { Unknown } \\
\text { Unknown }\end{array}$ & Unknown & Granato et al., 1996 \\
\hline
\end{tabular}


sites is necessary for effective glycinergic transmission and motor pattern generation. In bandoneon mutants, GlyR cluster immunostaining in the spinal cord has a diffuse appearance rather than a clustered appearance, suggesting that GlyRb is necessary for the synaptic aggregation of $\alpha \beta$ GlyRs in zebrafish (Kirsch et al., 1993; Meyer et al., 1995; Feng et al., 1998; Kim et al., 2006).

\section{Defective GlyT1 in the shocked Mutant}

Shocked (sho) carries a mutation in slc6a9, which encodes GlyT1. Three mutant alleles of slc6a9 were identified in the Tübingen screen (ta229g $=$ G81D, te301 $=$ C305Y and ta51e $=$ unknown), and these sho mutants exhibit trunk twitching instead of swimming in response to tactile stimuli at $2 \mathrm{dpf}$ (Granato et al., 1996; Luna et al., 2004; Cui et al., 2005; Mongeon et al., 2008). In addition, the frequency of spontaneous coiling is reduced and the escape contraction at $1 \mathrm{dpf}$ is abolished in sho mutants. An electrophysiological analysis revealed that tactile stimuli induces arrhythmic muscle activation in sho mutants rather than the rhythmic depolarization observed in wild-type muscle (Cui et al., 2004). The ta229g allele, which produces the strongest phenotype, results from a G81D missense mutation that disrupts GlyT1 function (Cui et al., 2005). Increased extracellular glycine is thought to be the cause of the sho mutant phenotype. This presumption is supported by the following observations. First, the perfusion of glycine-free cerebrospinal fluid following the removal of the dorsal roof of the fourth ventricle recovers touchevoked swimming in sho mutants, and this effect is lost when glycine is added to the perfusate (Cui et al., 2005; Mongeon et al., 2008). Second, the application of low concentrations of strychnine to sho mutants leads to partial motor recovery, similar to observations in GlyT1 knockout mice (Gomeza et al., 2003a; Cui et al., 2005). Thus, a lack of functional GlyT1 and elevated extracellular glycine are likely to underlie the potentiation of glycinergic transmission in the sho phenotype.

The GlyT1 knockout mice exhibited severe motor and respiratory defects and die at birth due to the respiratory defect (Gomeza et al., 2003a), whereas the GlyT1 defective zebrafishes exhibit a motility recovery by $4-5 \mathrm{dpf}$ and survive thereafter (Mongeon et al., 2008). The motility recovery was accompanied by a reduction in GlyR expression that leads to a decrease in the amplitude of inhibitory potentials enhanced by the GlyT1 mutant (Mongeon et al., 2008). Although the alteration of GlyR expression may represent compensatory mechanisms, the molecular basis for this compensation is not revealed.

Glycinergic transporter 1 dysfunction has been posited in the pathogenesis of glycine encephalopathy, which is characterized by respiratory impairment (Gomeza et al., 2003a; Applegarth and Toone, 2004, 2006; Harvey et al., 2008b), and schizophrenia which may be arose from hypofunction of NMDAR (Krystal et al., 1994; Lahti et al., 2001; Tsai et al., 2004; Dalmau et al., 2007). Animal models are clearly required to investigate the biological roles of GlyT1 in the context of human disorders, and zebrafish may provide particular advantages in future efforts. For example, while GlyT1 knockout mice die on the first postnatal day due to severe respiratory deficits (Gomeza et al., 2003a; Tsai et al., 2004), zebrafish sho mutants can survive well into adulthood through careful feeding and are thus useful as a physiologically relevant animal model for GlyT1 dysfunction.

\section{CONCLUSION}

Functional GlyRs are $\alpha$ homomeric or $\alpha \beta$ heteromeric pentamers. Electrophysiological studies of $\alpha$ subunits in cultured cells have shown the difference in conductance and kinetics of each $\alpha$ subunit (Takahashi et al., 1992; Bormann et al., 1993; Rajendra et al., 1995; Beato et al., 2002; Mangin et al., 2003; Burzomato et al., 2004; Zhang et al., 2015). Moreover, both in zebrafish and in mammals, each $\alpha$ subunit exhibits a distinct pattern of temporal and spatial expression in the CNS. This diversity of the $\alpha$ subunits suggests that GlyRs play various roles in physiological functions. However, the details of these physiological roles are not well understood. Several studies have identified GlyR subunit selective modulator in Cannabinoids and endocannabinoid (Hejazi et al., 2006; Yang et al., 2008; Xiong et al., 2012), in compounds isolated from ginkgo and Australian marine sponges (Balansa et al., 2010, 2013a,b; Maleeva et al., 2015). Furthermore, recent publications have reported that heptapeptide exhibit the subunit selective modulating effects on $\alpha 1 \beta$ and $\alpha 3 \beta$ heteromeric receptor with zinc ion dependence (Cornelison et al., 2016). These subunitselective modulators would be useful tool to investigate the physiological roles of GlyR subunits in CNS. Together with the selective modulator, losses of function mutants of each GlyR subunit are powerful tools for uncovering the specific functions of each GlyR subunit. Now, zebrafish provide a cheaper, more convenient and highly useful alternative animal model for the study of GlyRs and glycinergic transmission. So far, the glrbb and slc6a9 mutants have been used to investigate the glycinergic synapse. Future work can further utilize CRISPR/Cas9-mediated gene disruption in zebrafish. In addition, in vivo observations of the glycinergic synapse in living zebrafish are a powerful method for the study of glycinergic synapse formation and plasticity. Taken together, a combination of readily available genetic mutants and innovative imaging techniques in zebrafish is sure to accelerate our understanding of glycinergic neurotransmission in the future.

\section{AUTHOR CONTRIBUTIONS}

All authors listed, have made substantial, direct and intellectual contribution to the work, and approved it for publication.

\section{ACKNOWLEDGMENTS}

We apologize to investigators whose work could not be cited in this manuscript owing to space limitations. This work was supported by a Grant-in-Aid for Young Scientists (B) from the Ministry of Education, Culture, Sports, Science, and Technology of Japan (MEXT) to KO and Grant-in-Aid for Scientific Research (B) from the MEXT, the Takeda Science Foundation, the Mochida Memorial Foundation for Medical and Pharmaceutical Research, the Naito Foundation, and the Suzuken Memorial Foundation and the Japan Epilepsy Research Foundation to HH. 


\section{REFERENCES}

Aguayo, L. G., Castro, P., Mariqueo, T., Muñoz, B., Xiong, W., Zhang, L., et al. (2014). Altered sedative effects of ethanol in mice with al glycine receptor subunits that are insensitive to Gbg modulation. Neuropsychopharmacology 39, 2538-2548. doi: 10.1038/npp.2014.100

Ahmadi, S., Lippross, S., Neuhuber, W. L., and Zeilhofer, H. U. (2002). PGE2 selectively blocks inhibitory glycinergic neurotransmission onto rat superficial dorsal horn neurons. Nat. Neurosci. 5, 34-40. doi: 10.1038/nn778

Akerboom, J., Chen, T. W., Wardill, T. J., Tian, L., Marvin, J. S., Mutlu, S., et al. (2012). Optimization of a GCaMP calcium indicator for neural activity imaging. J. Neurosci. 32, 13819-13840. doi: 10.1523/JNEUROSCI.2601-12.2012

Akitake, C. M., Macurak, M., Halpern, M. E., and Goll, M. G. (2011). Transgenerational analysis of transcriptional silencing in zebrafish. Dev. Biol. 352, 191-201. doi: 10.1016/j.ydbio.2011.01.002

Allain, A. E., Cazenave, W., Delpy, A., Exertier, P., Barthe, C., Meyrand, P., et al. (2015-2016). Nonsynaptic glycine release is involved in the early KCC2 expression. Dev. Neurobiol. 76, 764-779. doi: 10.1002/dneu.22358

Al-Owain, M., Colak, D., Al-Bakheet, A., Al-Hashmi, N., Shuaib, T., AlHemidan, A., et al. (2012). Novel mutation in GLRB in a large family with hereditary hyperekplexia. Clin. Genet. 81, 479-484. doi: 10.1111/j.13990004.2011.01661.x

Amores, A., Force, A., Yan, Y.-L., Joly, L., Amemiya, C., Fritz, A., et al. (1998). Zebrafish hox clusters and vertebrate genome evolution. Science 282, 17111714. doi: 10.1126/science.282.5394.1711

Applegarth, D. A., and Toone, J. R. (2004). Glycine encephalopathy (nonketotic hyperglycinaemia): review and update. J. Inherit. Metab. Dis. 27, 417-422. doi: 10.1023/B:BOLI.0000031222.38328.59

Applegarth, D. A., and Toone, J. R. (2006). Glycine encephalopathy (nonketotic hyperglycinemia): comments and speculations. Am. J. Med. Genet. Part A 140, 186-188. doi: 10.1002/ajmg.a.31030

Aroeira, R. I., Ribeiro, J. A., Sebastião, A. M., and Valente, C. A. (2011). Age-related changes of glycine receptor at the rat hippocampus: from the embryo to the adult. J. Neurochem. 118, 339-353. doi: 10.1111/j.1471-4159.2011.07197.x

Arrenberg, A. B., Del Bene, F., and Baier, H. (2009). Optical control of zebrafish behavior with halorhodopsin. Proc. Natl. Acad. Sci. U.S.A. 106, 17968-17973. doi: $10.1073 /$ pnas.0906252106

Asakawa, K., and Kawakami, K. (2008). Targeted gene expression by the Gal4-UAS system in zebrafish. Dev. Growth Differ. 50, 391-399. doi: 10.1111/j.1440169X.2008.01044.x

Asakawa, K., Suster, M. L., Mizusawa, K., Nagayoshi, S., Kotani, T., Urasaki, A., et al. (2008). Genetic dissection of neural circuits by Tol2 transposon-mediated Gal4 gene and enhancer trapping in zebrafish. Proc. Natl. Acad. Sci. U.S.A. 105, 1255-1260. doi: 10.1073/pnas.0704963105

Auer, T. O., Duroure, K., De Cian, A., Concordet, J. P., and Del Bene, F. (2014). Highly efficient CRISPR/Cas9-mediated knock-in in zebrafish by homology-independent DNA repair. Genome Res. 24, 142-153. doi: 10.1101/gr. 161638.113

Avila, A., Vidal, P. M., Dear, T. N., Harvey, R. J., Rigo, J. M., and Nguyen, L. (2013). Glycine receptor a2 subunit activation promotes cortical interneuron migration. Cell Rep. 4, 738-750. doi: 10.1016/j.celrep.2013.07.016

Avila, A., Vidal, P. M., Tielens, S., Morelli, G., Laguesse, S., Harvey, R. J., et al. (2014). Glycine receptors control the generation of projection neurons in the developing cerebral cortex. Cell Death Differ. 21, 1696-1708. doi: 10.1038/cdd.2014.75

Baba, H., Kohno, T., Moore, K. A., and Woolf, C. J. (2001). Direct activation of rat spinal dorsal horn neurons by prostaglandin E2. J. Neurosci. 21, 1750-1756.

Baird, G. S., Zacharias, D. A., and Tsien, R. Y. (1999). Circular permutation and receptor insertion within green fluorescent proteins. Proc. Natl. Acad. Sci. U.S.A. 96, 11241-11246. doi: 10.1073/pnas.96.20.11241

Balansa, W., Islam, R., Fontaine, F., Piggott, A. M., Zhang, H., Webb, T. I., et al. (2010). Ircinialactams: subunit-selective glycine receptor modulators from Australian sponges of the family Irciniidae. Bioorg. Med. Chem. 18, 2912-2919. doi: 10.1016/j.bmc.2010.03.002

Balansa, W., Islam, R., Gilbert, D. F., Fontaine, F., Xiao, X., Zhang, H., et al. (2013a). Australian marine sponge alkaloids as a new class of glycine-gated chloride channel receptor modulator. Bioorg. Med. Chem. 21, 4420-4425. doi: 10.1016/j.bmc.2013.04.061
Balansa, W., Islam, R., Fontaine, F., Piggott, A. M., Zhang, H., Xiao, X., et al. (2013b). Sesterterpene glycinyl-lactams: a new class of glycine receptor modulator from Australian marine sponges of the genus Psammocinia. Org. Biomol. Chem. 11, 4695-4701. doi: 10.1039/C3OB40861B

Baraban, S. C., Dinday, M. T., and Hortopan, G. A. (2013). Drug screening in Scnla zebrafish mutant identifies clemizole as a potential Dravet syndrome treatment. Nat. Commun. 4:2410. doi: 10.1038/ncomms3410

Barrangou, R., Fremaux, C., Deveau, H., Richards, M., Boyaval, P., Moineau, S., et al. (2007). CRISPR provides acquired resistance against viruses in prokaryotes. Science 315, 1709-1712. doi: 10.1126/science. 1138140

Bassett, D. I., Bryson-Richardson, R. J., Daggett, D. F., Gautier, P., Keenan, D. G., and Currie, P. D. (2003). Dystrophin is required for the formation of stable muscle attachments in the zebrafish embryos. Development 130, 5851-5860. doi: 10.1242/dev.00799

Beato, M., Groot-Kormelink, P. J., Colquhoun, D., and Sivilotti, L. G. (2002). Openings of the rat recombinant $\alpha 1$ homomeric glycine receptor as a function of the number of agonist molecules bound. J. Gen. Physiol. 119, 443-466. doi: 10.1085/jgp.20028530

Becker, C. M., Hoch, W., and Betz, H. (1988). Glycine receptor heterogeneity in rat spinal cord during postnatal development. EMBO J. 7, 3717.

Bedell, V. M., Wang, Y., Campbell, J. M., Poshusta, T. L., Starker, C. G., Krug, R. G. II, et al. (2012). In vivo genome editing using a high-efficiency TALEN system. Nature 491, 114-118. doi: 10.1038/nature11537

Behra, M., Cousin, X., Bertrand, C., Vonesch, J. L., Biellmann, D., Chatonnet, A., et al. (2002). Acetylcholinesterase is required for neuronal and muscular development in the zebrafish embryo. Nat. Neurosci. 5, 111-118. doi: $10.1038 / \mathrm{nn} 788$

Ben-Ari, Y. (2002). Excitatory actions of GABA during development: the nature of the nurture. Nat. Rev. Neurosci. 3, 728-739. doi: 10.1038/nrn920

Betz, H., Gomeza, J., Armsen, W., Scholze, P., and Eulenburg, V. (2006). Glycine transporters: essential regulators of synaptic transmission. Biochem. Soc. Trans. 34, 55-58. doi: 10.1042/BST0340055

Blednov, Y. A., Benavidez, J. M., Homanics, G. E., and Harris, R. A. (2012). Behavioral characterization of knockin mice with mutations M287L and Q266I in the glycine receptor $\alpha 1$ subunit. J. Pharmacol. Exp. Ther. 340, 317-329. doi: 10.1124/jpet.111.185124

Blednov, Y. A., Benavidez, J. M., Black, M., Leiter, C. R., Osterndorff-Kahanek, E., and Harris, R. A. (2015). Glycine receptors containing $\alpha 2$ or $\alpha 3$ subunits regulate specific ethanol-mediated behaviors. J. Pharm. Exp. Ther. 353, 181-191. doi: 10.1124/jpet.114.221895

Boch, J., Scholze, H., Schornack, S., Landgraf, A., Hahn, S., Kay, S., et al. (2009). Breaking the code of DNA binding specificity of TAL-type III effectors. Science 326, 1509-1512. doi: 10.1126/science.1178811

Bode, A., and Lynch, J. W. (2014). The impact of human hyperekplexia mutations on glycine receptor structure and function. Mol. Brain. 7:1. doi: 10.1186/17566606-7-2

Bormann, J., Rundström, N., Betz, H., and Langosch, D. (1993). Residues within transmembrane segment M2 determine chloride conductance of glycine receptor homo-and hetero-oligomers. EMBO J. 12, 3729-3737.

Brackmann, M., Zhao, C., Schmieden, V., and Braunewell, K. H. (2004). Cellular and subcellular localization of the inhibitory glycine receptor in hippocampal neurons. Biochem. Biophys. Res. Commun. 324, 1137-1142. doi: 10.1016/j.bbrc.2004.09.172

Brand, A. H., and Perrimon, N. (1993). Targeted gene expression as a means of altering cell fates and generating dominant phenotypes. Development 118, 401-415.

Brustein, E., Côté, S., Ghislain, J., and Drapeau, P. (2013). Spontaneous glycineinduced calcium transients in spinal cord progenitors promote neurogenesis. Dev. Neurobiol. 73, 168-175. doi: 10.1002/dneu.22050

Burzomato, V., Beato, M., Groot-Kormelink, P. J., Colquhoun, D., and Sivilotti, L. G. (2004). Single-channel behavior of heteromeric $\alpha 1 \beta$ glycine receptors: an attempt to detect a conformational change before the channel opens. J. Neurosci. 24, 10924-10940. doi: 10.1523/JNEUROSCI.3424-04.2004

Burzomato, V., Groot-Kormelink, P. J., Sivilotti, L. G., and Beato, M. (2003). Stoichiometry of recombinant heteromeric glycine receptors revealed by a pore-lining region point mutation. Receptors Channels 9, 353-361. doi: $10.3109 / 714041016$ 
Buss, R. R., and Drapeau, P. (2001). Synaptic drive to motoneurons during fictive swimming in the developing zebrafish. J. Neurophysiol. 86, 197-210.

Cade, L., Reyon, D., Hwang, W. Y., Tsai, S. Q., Patel, S., Khayter, C., et al. (2012). Highly efficient generation of heritable zebrafish gene mutations using homo-and heterodimeric TALENs. Nucleic Acids Res. 40, 8001-8010. doi: 10.1093/nar/gks518

Calamai, M., Specht, C. G., Heller, J., Alcor, D., Machado, P., Vannier, C., et al. (2009). Gephyrin oligomerization controls GlyR mobility and synaptic clustering. J. Neurosci. 29, 7639-7648. doi: 10.1523/JNEUROSCI.5711-08.2009

Çalişkan, G., Müller, I., Semtner, M., Winkelmann, A., Raza, A. S., Hollnagel, J. O., et al. (2016). Identification of parvalbumin interneurons as cellular substrate of fear memory persistence. Cereb. Cortex 26, 2325-2340. doi: 10.1093/cercor/bhw001

Callister, R. J., and Graham, B. A. (2010). Early history of glycine receptor biology in mammalian spinal cord circuits. Front. Mol. Neurosci. 3:13. doi: $10.3389 /$ fnmol.2010.00013

Cao, Y., Semanchik, N., Lee, S. H., Somlo, S., Barbano, P. E., Coifman, R., et al. (2009). Chemical modifier screen identifies HDAC inhibitors as suppressors of PKD models. Proc. Natl. Acad. Sci. U.S.A. 106, 21819-21824. doi: 10.1073/pnas.0911987106

Carmean, V., Yonkers, M. A., Tellez, M. B., Willer, J. R., Willer, G. B., Gregg, R. G., et al. (2015). pigk Mutation underlies macho behavior and affects Rohon-Beard cell excitability. J. Neurophysiol. 114, 1146-1157. doi: 10.1152/jn.00355.2015

Carroll, D. (2011). Genome engineering with zinc-finger nucleases. Genetics 188, 773-782. doi: 10.1534/genetics.111.131433

Chang, N., Sun, C., Gao, L., Zhu, D., Xu, X., Zhu, X., et al. (2013). Genome editing with RNA-guided Cas9 nuclease in zebrafish embryos. Cell Res. 23, 465-472. doi: $10.1038 /$ cr.2013.45

Chattipakorn, S. C., and McMahon, L. L. (2002). Pharmacological characterization of glycine-gated chloride currents recorded in rat hippocampal slices. J. Neurophysiol. 87, 1515-1525.

Chattipakorn, S. C., and McMahon, L. L. (2003). Strychnine-sensitive glycine receptors depress hyperexcitability in rat dentate gyrus. J. Neurophysiol. 89, 1339-1342. doi: 10.1152/jn.00908.2002

Chen, R., Okabe, A., Sun, H., Sharopov, S., Hanganu-Opatz, I. L., Kolbaev, S. N., et al. (2014). Activation of glycine receptors modulates spontaneous epileptiform activity in the immature rat hippocampus. J. Physiol. 592, 21532168. doi: 10.1113/jphysiol.2014.271700

Chen, T. W., Wardill, T. J., Sun, Y., Pulver, S. R., Renninger, S. L., Baohan, A., et al. (2013). Ultrasensitive fluorescent proteins for imaging neuronal activity. Nature 499, 295-300. doi: 10.1038/nature12354

Chung, S. K., Bode, A., Cushion, T. D., Thomas, R. H., Hunt, C., Wood, S. E., et al. (2013). GLRB is the third major gene of effect in hyperekplexia. Hum. Mol. Genet. 22, 927-940. doi: 10.1093/hmg/dds498

Cong, L., Ran, F. A., Cox, D., Lin, S., Barretto, R., Habib, N., et al. (2013). Multiplex genome engineering using CRISPR/Cas systems. Science 339, 819-823. doi: $10.1126 /$ science. 1231143

Cornelison, G. L., Pflanz, N. C., Tipps, M. E., and Mihic, S. J. (2016). Identification and characterization of heptapeptide modulators of the glycine receptor. Eur. J. Pharmacol. 780, 252-259. doi: 10.1016/j.ejphar.2016.03.058

Cui, W. W., Low, S. E., Hirata, H., Saint-Amant, L., Geisler, R., Hume, R. I., et al. (2005). The zebrafish shocked gene encodes a glycine transporter and is essential for the function of early neural circuits in the CNS. J. Neurosci. 25, 6610-6620. doi: 10.1523/JNEUROSCI.5009-04.2005

Cui, W. W., Saint-Amant, L., and Kuwada, J. Y. (2004). shocked Gene is required for the function of a premotor network in the zebrafish CNS. J. Neurophysiol. 92, 2898-2908. doi: 10.1152/jn.00419.2004

Curtin, P. C., and Preuss, T. (2015). Glycine and GABAA receptors mediate tonic and phasic inhibitory processes that contribute to prepulse inhibition in the goldfish startle network. Front. Neural Circuits 9:12. doi: 10.3389/fncir.2015.00012

Dahan, M., Lévi, S., Luccardini, C., Rostaing, P., Riveau, B., and Triller, A. (2003). Diffusion dynamics of glycine receptors revealed by single-quantum dot tracking. Science 302, 442-445. doi: 10.1126/science. 1088525

Dahlem, T. J., Hoshijima, K., Jurynec, M. J., Gunther, D., Starker, C. G., Locke, A. S., et al. (2012). Simple methods for generating and detecting locusspecific mutations induced with TALENs in the zebrafish genome. PLoS Genet. 8:e1002861. doi: 10.1371/journal.pgen.1002861
Dalmau, J., Tüzün, E., Wu, H. Y., Masjuan, J., Rossi, J. E., Voloschin, A., et al. (2007). Paraneoplastic anti-N-methyl-D-aspartate receptor encephalitis associated with ovarian teratoma. Ann. Neurol. 61, 25-36. doi: 10.1002/ana.21050

Danglot, L., Rostaing, P., Triller, A., and Bessis, A. (2004). Morphologically identified glycinergic synapses in the hippocampus. Mol. Cell. Neurosci. 27, 394-403. doi: 10.1016/j.mcn.2004.05.007

Davidson, A. E., Balciunas, D., Mohn, D., Shaffer, J., Hermanson, S., Sivasubbu, S., et al. (2003). Efficient gene delivery and gene expression in zebrafish using the sleeping beauty transposon. Dev. Biol. 263, 191-202. doi: 10.1016/j.ydbio.2003.07.013

David-Watine, B., Goblet, C., de Saint Jan, D., Fucile, S., Devignot, V., Bregestovski, P., et al. (1999). Cloning, expression and electrophysiological characterization of glycine receptor alpha subunit from zebrafish. Neuroscience 90, 303-317. doi: 10.1016/S0306-4522(98)00430-8

Davies, J. S., Chung, S. K., Thomas, R. H., Robinson, A., Hammond, C. L., Mullins, J. G., et al. (2010). The glycinergic system in human startle disease: a genetic screening approach. Front. Mol. Neurosci. 3:8. doi: 10.3389/fnmol.2010.00008

Deleuze, C., Runquist, M., Orcel, H., Rabie, A., Dayanithi, G., Alonso, G., et al. (2005). Structural difference between heteromeric somatic and homomeric axonal glycine receptors in the hypothalamo-neurohypophysial system. Neuroscience 135, 475-483. doi: 10.1016/j.neuroscience.2005.05.024

Delpy, A., Allain, A. E., Meyrand, P., and Branchereau, P. (2008). NKCC1 cotransporter inactivation underlies embryonic development of chloridemediated inhibition in mouse spinal motoneuron. J. Physiol. 586, 1059-1075. doi: 10.1113/jphysiol.2007.146993

Devignot, V., De Carvalho, L. P., Bregestovski, P., and Goblet, C. (2003). A novel glycine receptor $\alpha \mathrm{Z} 1$ subunit variant in the zebrafish brain. Neuroscience 122, 449-457. doi: 10.1016/S0306-4522(03)00171-4

Douglass, A. D., Kraves, S., Deisseroth, K., Schier, A. F., and Engert, F. (2008). Escape behavior elicited by single, channelrhodopsin-2-evoked spikes in zebrafish somatosensory neurons. Curr. Biol. 18, 1133-1137. doi: 10.1016/j.cub.2008.06.077

Downes, G. B., and Granato, M. (2004). Acetylcholinesterase function is dispensable for sensory neurite growth but is critical for neuromuscular synapse stability. Dev. Biol. 270, 232-245. doi: 10.1016/j.ydbio.2004.02.027

Downes, G. B., and Granato, M. (2006). Supraspinal input is dispensable to generate glycine-mediated locomotive behaviors in the zebrafish embryo. J. Neurobiol. 66, 437-451. doi: 10.1002/neu.20226

Doyon, Y., McCammon, J. M., Miller, J. C., Faraji, F., Ngo, C., Katibah, G. E., et al. (2008). Heritable targeted gene disruption in zebrafish using designed zinc-finger nucleases. Nat. Biotechnol. 26, 702-708. doi: 10.1038/nbt1409

Drapeau, P., Ali, D. W., Buss, R. R., and Saint-Amant, L. (1999). In vivo recording from identifiable neurons of the locomotor network in the developing zebrafish. J. Neurosci. Methods 88, 1-13. doi: 10.1016/S0165-0270(99)00008-4

Drapeau, P., Saint-Amant, L., Buss, R. R., Chong, M., McDearmid, J. R., and Brustein, E. (2002). Development of the locomotor network in zebrafish. Prog. Neurobiol. 68, 85-111. doi: 10.1016/S0301-0082(02)00075-8

Durisic, N., Godin, A. G., Wever, C. M., Heyes, C. D., Lakadamyali, M., and Dent, J. A. (2012). Stoichiometry of the human glycine receptor revealed by direct subunit counting. J. Neurosci. 32, 12915-12920. doi: 10.1523/JNEUROSCI.2050-12.2012

Eaton, R. C., Bombardieri, R. A., and Meyer, D. L. (1977). The Mauthner-initiated startle response in teleost fish. J. Exp. Biol. 66, 65-81.

Ehrensperger, M. V., Hanus, C., Vannier, C., Triller, A., and Dahan, M. (2007). Multiple association states between glycine receptors and gephyrin identified by SPT analysis. Biophys. J. 92, 3706-3718. doi: 10.1529/biophysj.106.095596

Eichler, S. A., Förstera, B., Smolinsky, B., Jüttner, R., Lehmann, T. N., Fähling, M., et al. (2009). Splice-specific roles of glycine receptor $\alpha 3$ in the hippocampus. Eur. J. Neurosci. 30, 1077-1091. doi: 10.1111/j.1460-9568.2009.06903.x

Eichler, S. A., Kirischuk, S., Jüttner, R., Schafermeier, P. K., Legendre, P., Lehmann, T. N., et al. (2008). Glycinergic tonic inhibition of hippocampal neurons with depolarizing GABAergic transmission elicits histopathological signs of temporal lobe epilepsy. J. Cell. Mol. Med. 12, 2848-2866. doi: 10.1111/j.15824934.2008.00357.x

Ellingsen, S., Laplante, M. A., König, M., Kikuta, H., Furmanek, T., Hoivik, E. A., et al. (2005). Large-scale enhancer detection in the zebrafish genome. Development 132, 3799-3811. doi: 10.1242/dev.01951 
Etard, C., Behra, M., Fisher, N., Hutcheson, D., Geisler, R., and Strähle, U. (2007). The UCS factor Steif/Unc-45b interacts with the heat shock protein Hsp90a during myofibrillogenesis. Dev. Biol. 308, 133-143. doi: 10.1016/j.ydbio.2007.05.014

Eulenburg, V., Armsen, W., Betz, H., and Gomeza, J. (2005). Glycine transporters: essential regulators of neurotransmission. Trends Biochem. Sci. 30, 325-333. doi: 10.1016/j.tibs.2005.04.004

Felsenfeld, A. L., Walker, C., Westerfield, M., Kimmel, C., and Streisinger, G. (1990). Mutations affecting skeletal muscle myofibril structure in the zebrafish. Development 108, 443-459.

Feng, G., Tintrup, H., Kirsch, J., Nichol, M. C., Kuhse, J., Betz, H., et al. (1998). Dual requirement for gephyrin in glycine receptor clustering and molybdoenzyme activity. Science 282, 1321-1324. doi: 10.1126/science.282.5392.1321

Fetcho, J. R. (2007). The utility of zebrafish for studies of the comparative biology of motor systems. J. Exp. Zool. B Mol. Dev. Evol. 308, 550-562. doi: 10.1002/jez.b.21127

Flint, A. C., Liu, X., and Kriegstein, A. R. (1998). Nonsynaptic glycine receptor activation during early neocortical development. Neuron 20, 43-53. doi: 10.1016/S0896-6273(00)80433-X

Foley, J. E., Yeh, J. R. J., Maeder, M. L., Reyon, D., Sander, J. D., Peterson, R. T., et al. (2009). Rapid mutation of endogenous zebrafish genes using zinc finger nucleases made by Oligomerized Pool ENgineering (OPEN). PLoS ONE 4:e4348. doi: 10.1371/journal.pone.0004348

Friedrich, T., Lambert, A. M., Masino, M. A., and Downes, G. B. (2012). Mutation of zebrafish dihydrolipoamide branched-chain transacylase E2 results in motor dysfunction and models maple syrup urine disease. Dis. Model. Mech. 5, 248-258. doi: 10.1242/dmm.008383

Fritschy, J. M., Harvey, R. J., and Schwarz, G. (2008). Gephyrin: where do we stand, where do we go? Trends Neurosci. 31, 257-264. doi: 10.1016/j.tins.2008.02.006

Fu, Y., Foden, J. A., Khayter, C., Maeder, M. L., Reyon, D., Joung, J. K., et al. (2013). High-frequency off-target mutagenesis induced by CRISPR-Cas nucleases in human cells. Nat. Biotechnol. 31, 822-826. doi: 10.1038/nbt.2623

Fujita, M., Sato, K., Sato, M., Inoue, T., Kozuka, T., and Tohyama, M. (1991). Regional distribution of the cells expressing glycine receptor $\beta$ subunit mRNA in the rat brain. Brain Res. 560, 23-37. doi: 10.1016/0006-8993(91) 91210-R

Furukawa, H., Singh, S. K., Mancusso, R., and Gouaux, E. (2005). Subunit arrangement and function in NMDA receptors. Nature 438, 185-192. doi: 10.1038 /nature04089

Ganser, L. R., Yan, Q., James, V. M., Kozol, R., Topf, M., Harvey, R. J., et al. (2013). Distinct phenotypes in zebrafish models of human startle disease. Neurobiol. Dis. 60, 139-151. doi: 10.1016/j.nbd.2013.09.002

Garneau, J. E., Dupuis, M. È, Villion, M., Romero, D. A., Barrangou, R., Boyaval, P., et al. (2010). The CRISPR/Cas bacterial immune system cleaves bacteriophage and plasmid DNA. Nature 468, 67-71. doi: 10.1038/nature09523

Gleason, M. R., Armisen, R., Verdecia, M. A., Sirotkin, H., Brehm, P., and Mandel, G. (2004). A mutation in serca underlies motility dysfunction in accordion zebrafish. Dev. Biol. 276, 441-451. doi: 10.1016/j.ydbio.2004. 09.008

Gleason, M. R., Higashijima, S. I., Dallman, J., Liu, K., Mandel, G., and Fetcho, J. R. (2003). Translocation of CaM kinase II to synaptic sites in vivo. Nat. Neurosci. 6, 217-218. doi: 10.1038/nn1011

Goldsmith, P. (2004). Zebrafish as a pharmacological tool: the how, why and when. Curr. Opin. Pharmacol. 4, 504-512. doi: 10.1016/j.coph.2004.04.005

Goll, M. G., Anderson, R., Stainier, D. Y., Spradling, A. C., and Halpern, M. E. (2009). Transcriptional silencing and reactivation in transgenic zebrafish. Genetics 182, 747-755. doi: 10.1534/genetics.109.102079

Gomeza, J., Hülsmann, S., Ohno, K., Eulenburg, V., Szöke, K., Richter, D., et al. (2003a). Inactivation of the glycine transporter 1 gene discloses vital role of glial glycine uptake in glycinergic inhibition. Neuron 40, 785-796. doi: 10.1016/S0896-6273(03)00672-X

Gomeza, J., Ohno, K., Hülsmann, S., Armsen, W., Eulenburg, V., Richter, D. W., et al. (2003b). Deletion of the mouse glycine transporter 2 results in a hyperekplexia phenotype and postnatal lethality. Neuron 40, 797-806. doi: 10.1016/S0896-6273(03)00673-1

Granato, M., Van Eeden, F. J., Schach, U., Trowe, T., Brand, M., Furutani-Seiki, M., et al. (1996). Genes controlling and mediating locomotion behavior of the zebrafish embryo and larva. Development 123, 399-413.
Grenningloh, G., Pribilla, I., Prior, P., Multhaup, G., Beyreuther, K., Taleb, O., et al. (1990b). Cloning and expression of the $58 \mathrm{kd} \beta$ subunit of the inhibitory glycine receptor. Neuron 4, 963-970. doi: 10.1016/0896-6273(90)90149-A

Grenningloh, G., Rienitz, A., Schmitt, B., Methfessel, C., Zensen, M., Beyreuther, K., et al. (1987). The strychnine-binding subunit of the glycine receptor shows homology with nicotinic acetylcholine receptors. Nature 328, 215-220. doi: 10.1038/328215a0

Grenningloh, G., Schmieden, V., Schofield, P. R., Seeburg, P. H., Siddique, T., Mohandas, T. K., et al. (1990a). Alpha subunit variants of the human glycine receptor: primary structures, functional expression and chromosomal localization of the corresponding genes. EMBO J. 9, 771-776.

Griffon, N., Büttner, C., Nicke, A., Kuhse, J., Schmalzing, G., and Betz, H. (1999). Molecular determinants of glycine receptor subunit assembly. EMBO J. 18, 4711-4721. doi: 10.1093/emboj/18.17.4711

Grillner, S. (2003). The motor infrastructure: from ion channels to neuronal networks. Nat. Rev. Neurosci. 4, 573-586. doi: 10.1038/nrn1137

Grudzinska, J., Schemm, R., Haeger, S., Nicke, A., Schmalzing, G., Betz, H., et al. (2005). The $\beta$ subunit determines the ligand binding properties of synaptic glycine receptors. Neuron 45, 727-739. doi: 10.1016/j.neuron.2005.01.028

Grunwald, D. J., Kimmel, C. B., Westerfield, M., Walker, C., and Streisinger, G. (1988). A neural degeneration mutation that spares primary neurons in the zebrafish. Dev. Biol. 126, 115-128. doi: 10.1016/0012-1606(88)90245-X

Guyon, J. R., Goswami, J., Jun, S. J., Thorne, M., Howell, M., Pusack, T., et al. (2009). Genetic isolation and characterization of a splicing mutant of zebrafi sh dystrophin. Hum. Mol. Genet. 18, 202-211. doi: 10.1093/hmg/ddn337

Hall, T. E., Bryson-Richardson, R. J., Berger, S., Jacoby, A. S., Cole, N. J., Hollway, G. E., et al. (2007). The zebrafish candyfloss mutant implicates extracellular matrix adhesion failure in laminin $\alpha 2$ - deficient congenital muscular dystrophy. Proc. Natl. Acad. Sci. U.S.A. 104, 7092-7097. doi: 10.1073/pnas.0700942104

Halpern, M. E., Rhee, J., Goll, M. G., Akitake, C. M., Parsons, M., and Leach, S. D. (2008). Gal4/UAS transgenic tools and their application to zebrafish. Zebrafish 5, 97-110. doi: 10.1089/zeb.2008.0530

Han, L., Talwar, S., Wang, Q., Shan, Q., and Lynch, J. W. (2013). Phosphorylation of $\alpha 3$ glycine receptors induces a conformational change in the glycine-binding site. ACS Chem. Neurosci. 4, 1361-1370. doi: 10.1021/cn400097j

Hanus, C., Vannier, C., and Triller, A. (2004). Intracellular association of glycine receptor with gephyrin increases its plasma membrane accumulation rate. J. Neurosci. 24, 1119-1128. doi: 10.1523/JNEUROSCI.4380-03.2004

Harvey, R. J., Depner, U. B., Wässle, H., Ahmadi, S., Heindl, C., Reinold, H., et al. (2004). GlyR $\alpha 3$ : an essential target for spinal PGE2-mediated inflammatory pain sensitization. Science 304, 884-887. doi: 10.1126/science.1094925

Harvey, R. J., Schmieden, V., Von Holst, A., Laube, B., Rohrer, H., and Betz, H. (2000). Glycine receptors containing the $\alpha 4$ subunit in the embryonic sympathetic nervous system, spinal cord and male genital ridge. Eur. J. Neurosci. 12, 994-1001. doi: 10.1046/j.1460-9568.2000.00993.x

Harvey, R. J., Topf, M., Harvey, K., and Rees, M. I. (2008a). The genetics of hyperekplexia: more than startle! Trends Genet. 24, 439-447. doi: 10.1016/j.tig.2008.06.005

Harvey, R. J., Carta, E., Pearce, B. R., Chung, S. K., Supplisson, S., Rees, M. I., et al. (2008b). A critical role for glycine transporters in hyperexcitability disorders. Front. Mol. Neurosci. 1:1. doi: 10.3389/neuro.02.001.2008

Harvey, V. L., Caley, A., Müller, U. C., Harvey, R. J., and Dickenson, A. H. (2009). A selective role for $\alpha 3$ subunit glycine receptors in inflammatory pain. Front. Mol. Neurosci. 2:14. doi: 10.3389/neuro.02.014.2009

Haverkamp, S., Müller, U., Harvey, K., Harvey, R. J., Betz, H., and Wässle, H. (2003). Diversity of glycine receptors in the mouse retina: localization of the $\alpha 3$ subunit. J. Comp. Neurol. 465, 524-539. doi: 10.1002/cne.10852

Haverkamp, S., Müller, U., Zeilhofer, H. U., Harvey, R. J., and Wässle, H. (2004). Diversity of glycine receptors in the mouse retina: localization of the $\alpha 2$ subunit. J. Comp. Neurol. 477, 399-411. doi: 10.1002/cne.20267

Hawkins, T. A., Haramis, A.-P., Etard, C., Prodromou, C., Vaughan, C. K., Ashworth, R., et al. (2008). The ATPase-dependent chaperoning activity of Hsp90a regulates thick filament formation and integration during skeletal muscle myofibrillogenesis. Development 135, 1147-1156. doi: 10.1242/dev.018150

Heinze, L., Harvey, R. J., Haverkamp, S., and Wässle, H. (2007). Diversity of glycine receptors in the mouse retina: localization of the $\alpha 4$ subunit. J. Comp. Neurol. 500, 693-707. doi: 10.1002/cne.21201 
Hejazi, N., Zhou, C., Oz, M., Sun, H., Ye, J. H., and Zhang, L. (2006). $\Delta 9$-Tetrahydrocannabinol and endogenous cannabinoid anandamide directly potentiate the function of glycine receptors. Mol. Pharmacol. 69, 991-997. doi: 10.1124/mol.105.019174

Hensley, M. R., Emran, F., Bonilla, S., Zhang, L., Zhong, W., Grosu, P., et al. (2011). Cellular expression of Smarca4 (Brg1)-regulated genes in zebrafish retinas. BMC Dev. Biol. 11:45. doi: 10.1186/1471-213X-11-45

Herweg, J., and Schwarz, G. (2012). Splice-specific glycine receptor binding, folding, and phosphorylation of the scaffolding protein gephyrin. J. Biol. Chem. 287, 12645-12656. doi: 10.1074/jbc.M112.341826

Higashijima, S. I., Masino, M. A., Mandel, G., and Fetcho, J. R. (2004). Engrailed-1 expression marks a primitive class of inhibitory spinal interneuron. J. Neurosci. 24, 5827-5839. doi: 10.1523/JNEUROSCI.5342-03.2004

Hirata, H., Carta, E., Yamanaka, I., Harvey, R. J., and Kuwada, J. Y. (2010). Defective glycinergic synaptic transmission in zebrafish motility mutants. Front. Mol. Neurosci. 2:26. doi: 10.3389/neuro.02.026.2009

Hirata, H., Saint-Amant, L., Downes, G. B., Cui, W. W., Zhou, W., Granato, M., et al. (2005). Zebrafish bandoneon mutants display behavioral defects due to a mutation in the glycine receptor $\beta$-subunit. Proc. Natl. Acad. Sci. U.S.A. 102, 8345-8350. doi: 10.1073/pnas.0500862102

Hirata, H., Saint-Amant, L., Waterbury, J., Cui, W. W., Zhou, W., Li, Q., et al. (2004). accordion, a zebrafish behavioral mutant, has a muscle relaxation defect due to a mutation in the ATPase Ca2+ pump SERCA1. Development 131, 5457-5468. doi: 10.1242/dev.01410

Hirata, H., Watanabe, T., Hatakeyama, J., Sprague, S. M., Saint-Amant, L., Nagashima, A., et al. (2007). Zebrafish relatively relaxed mutants have a ryanodine receptor defect, show slow swimming and provide a model of multi-minicore disease. Development 134, 2771-2781. doi: 10.1242/dev.004531

Hisano, Y., Sakuma, T., Nakade, S., Ohga, R., Ota, S., Okamoto, H., et al. (2015). Precise in-frame integration of exogenous DNA mediated by CRISPR/Cas 9 system in zebrafish. Sci. Rep. 5:8841. doi: 10.1038/srep08841

Horvath, P., and Barrangou, R. (2010). CRISPR/Cas, the immune system of bacteria and archaea. Science 327, 167-170. doi: 10.1126/science.1179555

Hruscha, A., Krawitz, P., Rechenberg, A., Heinrich, V., Hecht, J., Haass, C., et al. (2013). Efficient CRISPR/Cas9 genome editing with low off-target effects in zebrafish. Development 140, 4982-4987. doi: 10.1242/dev.099085

Hruskova, B., Trojanova, J., Kulik, A., Kralikova, M., Pysanenko, K., Bures, Z., et al. (2012). Differential distribution of glycine receptor subtypes at the rat calyx of held synapse. J. Neurosci. 32, 17012-17024. doi: 10.1523/JNEUROSCI.154712.2012

Hsu, P. D., Scott, D. A., Weinstein, J. A., Ran, F. A., Konermann, S., Agarwala, V., et al. (2013). DNA targeting specificity of RNA-guided Cas9 nucleases. Nat. Biotechnol. 31, 827-832. doi: 10.1038/nbt.2647

Hwang, W. Y., Fu, Y., Reyon, D., Maeder, M. L., Tsai, S. Q., Sander, J. D., et al. (2013). Efficient genome editing in zebrafish using a CRISPR-Cas system. Nat. Biotechnol. 31, 227-229. doi: 10.1038/nbt.2501

Imboden, M., de Saint Jan, D., Leulier, F., Korn, H., Goblet, C., and Bregestovski, P. (2001a). Isolation and characterization of an alpha2type zebrafish glycine receptor subunit. Neuroscience 103, 799-810. doi: 10.1016/S0306-4522(00)00575-3

Imboden, M., Devignot, V., and Goblet, C. (2001b). Phylogenetic relationships and chromosomal location of five distinct glycine receptor subunit genes in the teleost Danio rerio. Dev. Genes. Evol. 211, 415-422. doi: 10.1007/s004270100164

Imboden, M., Devignot, V., Korn, H., and Goblet, C. (2001c). Regional distribution of glycine receptor messenger RNA in the central nervous system of zebrafish. Neuroscience 103, 811-830. doi: 10.1016/S0306-4522(00)00576-5

Inbal, A., Topczewski, J., and Solnica-Krezel, L. (2006). Targeted gene expression in the zebrafish prechordal plate. Genesis 44, 584-588. doi: 10.1002/dvg.20253

Ivanova, E., Müller, U., and Wässle, H. (2006). Characterization of the glycinergic input to bipolar cells of the mouse retina. Eur. J. Neurosci. 23, 350-364. doi: 10.1111/j.1460-9568.2005.04557.x

James, V. M., Bode, A., Chung, S. K., Gill, J. L., Nielsen, M., Cowan, F. M., et al. (2013). Novel missense mutations in the glycine receptor $\beta$ subunit gene (GLRB) in startle disease. Neurobiol. Dis. 52, 137-149. doi: 10.1016/j.nbd.2012.12.001

Jao, L. E., Wente, S. R., and Chen, W. (2013). Efficient multiplex biallelic zebrafish genome editing using a CRISPR nuclease system. Proc. Natl. Acad. Sci. U.S.A. 110, 13904-13909. doi: 10.1073/pnas.1308335110
Jeong, H. J., Jang, I. S., Moorhouse, A. J., and Akaike, N. (2003). Activation of presynaptic glycine receptors facilitates glycine release from presynaptic terminals synapsing onto rat spinal sacral dorsal commissural nucleus neurons. J. Physiol. 550, 373-383. doi: 10.1113/jphysiol.2003.041053

Jiang, Z., Yang, J., Purpura, L. A., Liu, Y., Ripps, H., and Shen, W. (2014). Glycinergic feedback enhances synaptic gain in the distal retina. J. Physiol. 592, 1479-1492. doi: 10.1113/jphysiol.2013.265785

Jinek, M., Chylinski, K., Fonfara, I., Hauer, M., Doudna, J. A., and Charpentier, E. (2012). A programmable dual-RNA-guided DNA endonuclease in adaptive bacterial immunity. Science 337, 816-821. doi: 10.1126/science.12 25829

Jing, L., Lefebvre, J. L., Gordon, L. R., and Granato, M. (2009). Wnt signals organize synaptic prepattern and axon guidance through the zebrafi sh unplugged/MuSK receptor. Neuron 61, 721-733. doi: 10.1016/j.neuron.2008.12.025

Johnson, J. W., and Ascher, P. (1987). Glycine potentiates the NMDA response in cultured mouse brain neurons. Nature 325, 529-531. doi: 10.1038/325529a0

Jonsson, S., Adermark, L., Ericson, M., and Söderpalm, B. (2014). The involvement of accumbal glycine receptors in the dopamine-elevating effects of addictive drugs. Neuropharmacol. 82, 69-75. doi: 10.1016/j.neuropharm.2014.03.010

Jonsson, S., Morud, J., Pickering, C., Adermark, L., Ericson, M., and Söderpalm, B. (2012). Changes in glycine receptor subunit expression in forebrain regions of the Wistar rat over development. Brain Res. 1446, 12-21. doi: 10.1016/j.brainres.2012.01.050

Jusuf, P. R., Haverkamp, S., and Grünert, U. (2005). Localization of glycine receptor alpha subunits on bipolar and amacrine cells in primate retina. J. Comp. Neurol. 488, 113-128. doi: 10.1002/cne.20555

Kanaka, C., Ohno, K., Okabe, A., Kuriyama, K., Itoh, T., Fukuda, A., et al. (2001). The differential expression patterns of messenger RNAs encoding $\mathrm{K}-\mathrm{Cl}$ cotransporters $(\mathrm{KCCl}, 2)$ and $\mathrm{Na}-\mathrm{K}-2 \mathrm{Cl}$ cotransporter $(\mathrm{NKCC} 1)$ in the rat nervous system. Neuroscience 104, 933-946. doi: 10.1016/S03064522(01)00149-X

Karlsson, J., von Hofsten, J., and Olsson, P. E. (2001). Generating transparent zebrafish: a refined method to improve detection of gene expression during embryonic development. Mar. Biotechnol. 3, 522-527. doi: 10.1007/s10126010053-4

Kawahara, G., Karpf, J. A., Myers, J. A., Alexander, M. S., Guyon, J. R., and Kunkel, L. M. (2011). Drug screening in a zebrafish model of Duchenne muscular dystrophy. Proc. Natl. Acad. Sci. U.S.A. 108, 5331-5336. doi: 10.1073/pnas.1102116108

Kawakami, K., Abe, G., Asada, T., Asakawa, K., Fukuda, R., Ito, A., et al. (2010). z Trap: zebrafish gene trap and enhancer trap database. BMC Dev. Biol. 10:105. doi: 10.1186/1471-213X-10-105

Kawakami, K., Takeda, H., Kawakami, N., Kobayashi, M., Matsuda, N., and Mishina, M. (2004). A transposon-mediated gene trap approach identifies developmentally regulated genes in zebrafish. Dev. Cell 7, 133-144. doi: 10.1016/j.devcel.2004.06.005

Kettleborough, R. N., Busch-Nentwich, E. M., Harvey, S. A., Dooley, C. M., de Bruijn, E., van Eeden, F., et al. (2013). A systematic genome-wide analysis of zebrafish protein-coding gene function. Nature 496, 494-497. doi: $10.1038 /$ nature11992

Kim, E. Y., Schrader, N., Smolinsky, B., Bedet, C., Vannier, C., Schwarz, G., et al. (2006). Deciphering the structural framework of glycine receptor anchoring by gephyrin. EMBO J. 25, 1385-1395. doi: 10.1038/sj.emboj.7601029

Kimmel, C. B., Ballard, W. W., Kimmel, S. R., Ullmann, B., and Schilling, T. F. (1995). Stages of embryonic development of the zebrafish. Dev. Dyn. 203, 253-310. doi: 10.1002/aja.1002030302

Kimura, Y., Hisano, Y., Kawahara, A., and Higashijima, S. I. (2014). Efficient generation of knock-in transgenic zebrafish carrying reporter/driver genes by CRISPR/Cas9-mediated genome engineering. Sci. Rep. 4:6545. doi: 10.1038/srep06545

Kimura, Y., Okamura, Y., and Higashijima, S. I. (2006). alx, a zebrafish homolog of Chx10, marks ipsilateral descending excitatory interneurons that participate in the regulation of spinal locomotor circuits. J. Neurosci. 26, 5684-5697. doi: 10.1523/JNEUROSCI.4993-05.2006

Kirchner, A., Breustedt, J., Rosche, B., Heinemann, U. F., and Schmieden, V. (2003). Effects of taurine and glycine on epileptiform activity induced by removal of $\mathrm{Mg} 2+$ in combined rat entorhinal cortex-hippocampal slices. Epilepsia 44, 1145-1152. doi: 10.1046/j.1528-1157.2003.01603.x 
Kirsch, J., and Betz, H. (1998). Glycine-receptor activation is required for receptor clustering in spinal neurons. Nature 392, 717-720. doi: 10.1038/33694

Kirsch, J., Wolters, I., Triller, A., and Betz, H. (1993). Gephyrin antisense oligonucleotides prevent glycine receptor clustering in spinal neurons. Nature 366, 745-748. doi: 10.1038/366745a0

Kneussel, M., and Betz, H. (2000). Clustering of inhibitory neurotransmitter receptors at developing postsynaptic sites: the membrane activation model. Trends Neurosci. 23, 429-435. doi: 10.1016/S0166-2236(00)01627-1

Kohashi, T., Nakata, N., and Oda, Y. (2012). Effective sensory modality activating an escape triggering neuron switches during early development in zebrafish. J. Neurosci. 32, 5810-5820. doi: 10.1523/JNEUROSCI.6169-11.2012

Kohashi, T., and Oda, Y. (2008). Initiation of Mauthner-or non-Mauthnermediated fast escape evoked by different modes of sensory input. J. Neurosci. 28, 10641-10653. doi: 10.1523/JNEUROSCI.1435-08.2008

Kok, F. O., Shin, M., Ni, C. W., Gupta, A., Grosse, A. S., van Impel, A., et al. (2015). Reverse genetic screening reveals poor correlation between morpholino-induced and mutant phenotypes in zebrafish. Dev. Cell 32, 97-108. doi: 10.1016/j.devcel.2014.11.018

Korn, H., and Faber, D. S. (2005). The Mauthner cell half a century later: a neurobiological model for decision-making? Neuron 47, 13-28. doi: 10.1016/j.neuron.2005.05.019

Korn, H., Oda, Y., and Faber, D. S. (1992). Long-term potentiation of inhibitory circuits and synapses in the central nervous system. Proc. Natl. Acad. Sci. U.S.A. 89, 440-443. doi: 10.1073/pnas.89.1.440

Krystal, J. H., Karper, L. P., Seibyl, J. P., Freeman, G. K., Delaney, R., Bremner, J. D., et al. (1994). Subanesthetic effects of the noncompetitive NMDA antagonist, ketamine, in humans: psychotomimetic, perceptual, cognitive, and neuroendocrine responses. Arch. Gen. Psychiatry 51, 199-214. doi: 10.1001/archpsyc.1994.03950030035004

Kubota, H., Alle, H., Betz, H., and Geiger, J. R. (2010). Presynaptic glycine receptors on hippocampal mossy fibers. Biochem. Biophys. Res. Commun. 393, 587-591. doi: 10.1016/j.bbrc.2010.02.019

Kuhse, J., Kuryatov, A., Maulet, Y., Malosio, M. L., Schmieden, V., and Betz, H. (1991). Alternative splicing generates two isoforms of the $\alpha 2$ subunit of the inhibitory glycine receptor. FEBS Lett. 283, 73-77. doi: 10.1016/00145793(91) 80557

Kuhse, J., Schmieden, V., and Betz, H. (1990). Identification and functional expression of a novel ligand binding subunit of the inhibitory glycine receptor. J. Biol. Chem. 265, 22317-22320.

Kunz, P. A., Burette, A. C., Weinberg, R. J., and Philpot, B. D. (2012). Glycine receptors support excitatory neurotransmitter release in developing mouse visual cortex. J. Physiol. 590, 5749-5764. doi: 10.1113/jphysiol.2012. 241299

Lahti, A. C., Weiler, M. A., Tamara, M., Parwani, A., and Tamminga, C. A. (2001). Effects of ketamine in normal and schizophrenic volunteers. Neuropsychopharmacology 25, 455-467. doi: 10.1016/S0893-133X(01)00243-3

Langosch, D., Thomas, L., and Betz, H. (1988). Conserved quaternary structure of ligand-gated ion channels: the postsynaptic glycine receptor is a pentamer. Proc. Natl. Acad. Sci. U.S.A. 85, 7394-7398. doi: 10.1073/pnas.85.19.7394

Lefebvre, J. L., Jing, L., Becaficco, S., Franzini-Armstrong, C., and Granato, M. (2007). Differential requirement for MuSK and dystroglycan in generating patterns of neuromuscular innervation. Proc. Natl. Acad. Sci. U.S.A. 104, 2483-2488. doi: 10.1073/pnas.0610822104

Legendre, P., Förstera, B., Jüttner, R., and Meier, J. C. (2009). Glycine receptors caught between genome and proteome-functional implications of RNA editing and splicing. Front. Mol. Neurosci. 2:23. doi: 10.3389/neuro.02.023. 2009

Legendre, P., and Korn, H. (1994). Glycinergic inhibitory synaptic currents and related receptor channels in the zebrafish brain. Eur. J. Neurosci. 6, 1544-1557. doi: 10.1111/j.1460-9568.1994.tb00545.x

Legendre, P., and Korn, H. (1995). Voltage dependence of conductance changes evoked by glycine release in the zebrafish brain. J. Neurophysiol. 73, 2404-2412.

Lévi, S., Schweizer, C., Bannai, H., Pascual, O., Charrier, C., and Triller, A. (2008). Homeostatic regulation of synaptic GlyR numbers driven by lateral diffusion. Neuron 59, 261-273. doi: 10.1016/j.neuron.2008.05.030

Li, D., Qiu, Z., Shao, Y., Chen, Y., Guan, Y., Liu, M., et al. (2013). Heritable gene targeting in the mouse and rat using a CRISPR-Cas system. Nat. Biotechnol. 31, 681-683. doi: $10.1038 /$ nbt.2661
Li, W., Teng, F., Li, T., and Zhou, Q. (2013). Simultaneous generation and germline transmission of multiple gene mutations in rat using CRISPR-Cas systems. Nat. Biotechnol. 31, 684-686. doi: 10.1038/nbt.2652

Liu, D., Wang, Z., Xiao, A., Zhang, Y., Li, W., Zu, Y., et al. (2014). Efficient gene targeting in zebrafish mediated by a zebrafish-codon-optimized cas 9 and evaluation of off-targeting effect. J. Genet. Genomics. 41, 43-46. doi: 10.1016/j.jgg.2013.11.004

Liu, Q., and Wong-Riley, M. T. (2013). Postnatal development of glycine receptor subunits $\alpha 1, \alpha 2, \alpha 3$, and $\beta$ immunoreactivity in multiple brain stem respiratory-related nuclear groups of the rat. Brain Res. 1538, 1-16. doi: 10.1016/j.brainres.2013.09.028

Love, D. R., Pichler, F. B., Dodd, A., Copp, B. R., and Greenwood, D. R. (2004). Technology for high-throughput screens: the present and future using zebrafish. Curr. Opin. Biotechnol. 15, 564-571. doi: 10.1016/j.copbio.2004.09.004

Low, S. E., Woods, I. G., Lachance, M., Ryan, J., Schier, A. F., and Saint-Amant, L. (2012). Touch responsiveness in zebrafish requires voltage-gated calcium channel 2.1 b. J. Neurophysiol. 108, 148-159. doi: 10.1152/jn.00839.2011

Luna, V. M., Wang, M., Ono, F., Gleason, M. R., Dallman, J. E., Mandel, G., et al. (2004). Persistent electrical coupling and locomotory dysfunction in the zebrafish mutant shocked. J. Neurophysiol. 92, 2003-2009. doi: 10.1152/jn.00454.2004

Maguire, E. P., Mitchell, E. A., Greig, S. J., Corteen, N., Balfour, D. J., Swinny, J. D., et al. (2014). Extrasynaptic glycine receptors of rodent dorsal raphe serotonergic neurons: a sensitive target for ethanol. Neuropsychopharmacology 39, 1232-1244. doi: 10.1038/npp.2013.326

Majumdar, S., Heinze, L., Haverkamp, S., Ivanova, E., and WÄssle, H. (2007). Glycine receptors of A-type ganglion cells of the mouse retina. Vis. Neurosci. 24, 471-487. doi: 10.1017/S0952523807070174

Majumdar, S., Weiss, J., and Wässle, H. (2009). Glycinergic input of widefield, displaced amacrine cells of the mouse retina. J. Physiol. 587, 3831-3849. doi: 10.1113/jphysiol.2009.171207

Maleeva, G., Buldakova, S., and Bregestovski, P. (2015). Selective potentiation of alpha 1 glycine receptors by ginkgolic acid. Front. Mol. Neurosci. 8:64. doi: 10.3389/fnmol.2015.00064

Mali, P., Yang, L., Esvelt, K. M., Aach, J., Guell, M., DiCarlo, J. E., et al. (2013). RNA-guided human genome engineering via Cas9. Science 339, 823-826. doi: 10.1126/science. 1232033

Malosio, M. L., Marqueze-Pouey, B., Kuhse, J., and Betz, H. (1991). Widespread expression of glycine receptor subunit mRNAs in the adult and developing rat brain. ЕМВО J. 10, 2401-2409.

Mangin, J. M., Baloul, M., Carvalho, L., Rogister, B., Rigo, J. M., and Legendre, P. (2003). Kinetic properties of the $\alpha 2$ homo-oligomeric glycine receptor impairs a proper synaptic functioning. J. Physiol. 553, 369-386. doi: 10.1113/jphysiol.2003.052142

Mangin, J. M., Guyon, A., Eugene, D., Paupardin-Tritsch, D., and Legendre, P. (2002). Functional glycine receptor maturation in the absence of glycinergic input in dopaminergic neurones of the rat substantia nigra. J. Physiol. 542, 685-697. doi: 10.1113/jphysiol.2002.018978

Masino, M. A., and Fetcho, J. R. (2005). Fictive swimming motor patterns in wild type and mutant larval zebrafish. J. Neurophysiol. 93, 3177-3188. doi: 10.1152/jn.01248.2004

McCool, B. A., and Botting, S. K. (2000). Characterization of strychnine-sensitive glycine receptors in acutely isolated adult rat basolateral amygdala neurons. Brain Res. 859, 341-351. doi: 10.1016/S0006-8993(00)02026-6

McCool, B. A., and Farroni, J. S. (2001). Subunit composition of strychninesensitive glycine receptors expressed by adult rat basolateral amygdala neurons. Eur. J. Neurosci. 14, 1082-1090. doi: 10.1046/j.0953-816x.2001.01730.x

McCracken, L. M., Blednov, Y. A., Trudell, J. R., Benavidez, J. M., Betz, H., and Harris, R. A. (2013a). Mutation of a zinc-binding residue in the glycine receptor al subunit changes ethanol sensitivity in vitro and alcohol consumption in vivo. J. Pharmacol. Exp. Ther. 344, 489-500. doi: 10.1124/jpet.112.197707

McCracken, L. M., Trudell, J. R., McCracken, M. L., and Harris, R. A. (2013b). Zinc-dependent modulation of a2- and a3-glycine receptor subunits by ethanol. Alcohol Clin. Exp. Res. 37, 2002-2010. doi: 10.1111/acer.12192

McDearmid, J. R., Liao, M., and Drapeau, P. (2006). Glycine receptors regulate interneuron differentiation during spinal network development. Proc. Natl. Acad. Sci. U.S.A. 103, 9679-9684. doi: 10.1073/pnas.0504871103 
McLean, D. L., Fan, J., Higashijima, S. I., Hale, M. E., and Fetcho, J. R. (2007). A topographic map of recruitment in spinal cord. Nature 446, 71-75. doi: 10.1038 /nature 05588

Meier, J., Vannier, C., Serge, A., Triller, A., and Choquet, D. (2001). Fast and reversible trapping of surface glycine receptors by gephyrin. Nat. Neurosci. 4, 253-260. doi: 10.1038/85099

Meng, X., Noyes, M. B., Zhu, L. J., Lawson, N. D., and Wolfe, S. A. (2008). Targeted gene inactivation in zebrafish using engineered zinc-finger nucleases. Nat. Biotechnol. 26, 695-701. doi: 10.1038/nbt1398

Meyer, G., Kirsch, J., Betz, H., and Langosch, D. (1995). Identification of a gephyrin binding motif on the glycine receptor $\beta$ subunit. Neuron 15, 563-572. doi: 10.1016/0896-6273(95)90145-0

Mikawa, S., Wang, C., Shu, F., Wang, T., Fukuda, A., and Sato, K. (2002). Developmental changes in KCC1, KCC2 and NKCC1 mRNAs in the rat cerebellum. Dev. Brain Res. 136, 93-100. doi: 10.1016/S0165-3806(02)00345-0

Miller, J. C., Tan, S., Qiao, G., Barlow, K. A., Wang, J., Xia, D. F., et al. (2011). A TALE nuclease architecture for efficient genome editing. Nat. Biotechnol. 29, 143-148. doi: 10.1038/nbt. 1755

Mine, J., Taketani, T., Otsubo, S., Kishi, K., and Yamaguchi, S. (2013). A 14-yearold girl with hyperekplexia having GLRB mutations. Brain Dev. 35, 660-663. doi: 10.1016/j.braindev.2012.10.013

Moens, C. B., Donn, T. M., Wolf-Saxon, E. R., and Ma, T. P. (2008). Reverse genetics in zebrafish by TILLING. Brief. Funct. Genomic. Proteomic. 7, 454-459. doi: 10.1093/bfgp/eln046

Molander, A., Löf, E., Stomberg, R., Ericson, M., and Söderpalm, B. (2005). Involvement of accumbal glycine receptors in the regulation of voluntary ethanol intake in the rat. Alcohol. Clin. Exp. Res. 29, 38-45. doi: 10.1097/01.ALC.0000150009.78622.E0

Molander, A., and Söderpalm, B. (2005). Accumbal strychnine-sensitive glycine receptors: an access point for ethanol to the brain reward system. Alcohol. Clin. Exp. Res. 29, 27-37. doi: 10.1097/01.ALC.0000150012.09608.81

Mongeon, R., Gleason, M. R., Masino, M. A., Fetcho, J. R., Mandel, G., Brehm, P., et al. (2008). Synaptic homeostasis in a zebrafish glial glycine transporter mutant. J. Neurophysiol. 100, 1716-1723. doi: 10.1152/jn.90596. 2008

Morelli, G., Avila, A., Ravanidis, S., Aourz, N., Neve, R. L., Smolders, I., et al. (2016). Cerebral cortical circuitry formation requires functional glycine receptors. Cereb. Cortex doi: 10.1093/cercor/bhw025 [Epub ahead of print].

Moscou, M. J., and Bogdanove, A. J. (2009). A simple cipher governs DNA recognition by TAL effectors. Science 326, 1501-1501. doi: 10.1126/science. 1178817

Mullins, M. C., Hammerschmidt, M., Haffter, P., and Nüsslein-Volhard, C. (1994). Large-scale mutagenesis in the zebrafish: in search of genes controlling development in a vertebrate. Curr. Biol. 4, 189-202. doi: 10.1016/S09609822(00)00048-8

Muto, A., Ohkura, M., Abe, G., Nakai, J., and Kawakami, K. (2013). Real-time visualization of neuronal activity during perception. Curr. Biol. 23, 307-311. doi: $10.1016 /$ j.cub.2012.12.040

Muto, A., Ohkura, M., Kotani, T., Higashijima, S. I., Nakai, J., and Kawakami, K. (2011). Genetic visualization with an improved GCaMP calcium indicator reveals spatiotemporal activation of the spinal motor neurons in zebrafish. Proc. Natl. Acad. Sci. U.S.A. 108, 5425-5430. doi: 10.1073/pnas.1000 887108

Myhre, J. L., Hills, J. A., Prill, K., Wohlgemuth, S. L., and Pilgrim, D. B. (2014). The titin A-band rod domain is dispensable for initial thick filament assembly in zebrafish. Dev. Biol. 387, 93-108. doi: 10.1016/j.ydbio.2013.12.020

Nakai, J., Ohkura, M., and Imoto, K. (2001). A high signal-to-noise Ca2+ probe composed of a single green fluorescent protein. Nat. Biotechnol. 19, 137-141. doi: $10.1038 / 84397$

Nasevicius, A., and Ekker, S. C. (2000). Effective targeted gene 'knockdown'in zebrafish. Nat. Genet. 26, 216-220. doi: 10.1038/79951

Niell, C. M., Meyer, M. P., and Smith, S. J. (2004). In vivo imaging of synapse formation on a growing dendritic arbor. Nat. Neurosci. 7, 254-260. doi: $10.1038 / \mathrm{nn} 1191$

Nobles, R. D., Zhang, C., Müller, U., Betz, H., and McCall, M. A. (2012). Selective glycine receptor $\alpha 2$ subunit control of crossover inhibition between the on and off retinal pathways. J. Neurosci. 32, 3321-3332. doi: 10.1523/JNEUROSCI.5341-11.2012
Oda, Y., Kawasaki, K., Morita, M., Korn, H., and Matsui, H. (1998). Inhibitory long-term potentiation underlies auditory conditioning of goldfish escape behaviour. Nature 394, 182-185. doi: 10.1038/28172

Ogino, K., Low, S. E., Yamada, K., Saint-Amant, L., Zhou, W., Muto, A., et al. (2015). RING finger protein 121 facilitates the degradation and membrane localization of voltage-gated sodium channels. Proc. Natl. Acad. Sci. U.S.A. 112, 2859-2864. doi: 10.1073/pnas.1414002112

Ohkura, M., Matsuzaki, M., Kasai, H., Imoto, K., and Nakai, J. (2005). Genetically encoded bright $\mathrm{Ca} 2+$ probe applicable for dynamic $\mathrm{Ca} 2+$ imaging of dendritic spines. Anal. Chem. 77, 5861-5869. doi: 10.1021/ac0506837

Olson, B. D., Sgourdou, P., and Downes, G. B. (2010). Analysis of a zebrafish behavioral mutant reveals a dominant mutation in atp2a1/SERCA1. Genesis 48 , 354-361. doi: 10.1002/dvg.20631

Ono, F., Higashijima, S. I., Shcherbatko, A., Fetcho, J. R., and Brehm, P. (2001). Paralytic zebrafish lacking acetylcholine receptors fail to localize rapsyn clusters to the synapse. J. Neurosci. 21, 5439-5448.

Ono, F., Mandel, G., and Brehm, P. (2004). Acetylcholine receptors direct rapsyn clusters to the neuromuscular synapse in zebrafish. J. Neurosci. 24, 5475-5481. doi: 10.1523/JNEUROSCI.0851-04.2004

Ono, F., Shcherbatko, A., Higashijima, S. I., Mandel, G., and Brehm, P. (2002). The zebrafish motility mutant twitch once reveals new roles for rapsyn in synaptic function. J. Neurosci. 22, 6491-6498.

Paik, E. J., de Jong, J. L., Pugach, E., Opara, P., and Zon, L. I. (2010). A chemical genetic screen in zebrafish for pathways interacting with $\mathrm{cdx} 4$ in primitive hematopoiesis. Zebrafish 7, 61-68. doi: 10.1089/zeb.2009.0643

Pang, S. C., Wang, H. P., Zhu, Z. Y., and Sun, Y. H. (2015). Transcriptional Activity and DNA Methylation Dynamics of the Gal4/UAS System in Zebrafish. Mar. Biotechnol. 17, 593-603. doi: 10.1007/s10126-015-9641-0

Paoletti, P., and Neyton, J. (2007). NMDA receptor subunits: function and pharmacology. Curr. Opin. Pharmacol. 7, 39-47. doi: 10.1016/j.coph.2006.08.011

Papouin, T., Ladépêche, L., Ruel, J., Sacchi, S., Labasque, M., Hanini, M., et al. (2012). Synaptic and extrasynaptic NMDA receptors are gated by different endogenous coagonists. Cell 150, 633-646. doi: 10.1016/j.cell.2012.06.029

Peal, D. S., Mills, R. W., Lynch, S. N., Mosley, J. M., Lim, E., Ellinor, P. T., et al. (2011). Novel chemical suppressors of long QT syndrome identified by an in vivo functional screen. Circulation 123, 23-30. doi: 10.1161/CIRCULATIONAHA.110.003

Peterson, R. T., Link, B. A., Dowling, J. E., and Schreiber, S. L. (2000). Small molecule developmental screens reveal the logic and timing of vertebrate development. Proc. Natl. Acad. Sci. U.S.A. 97, 12965-12969. doi: 10.1073/pnas.97.24.12965

Peterson, R. T., Shaw, S. Y., Peterson, T. A., Milan, D. J., Zhong, T. P., Schreiber, S. L., et al. (2004). Chemical suppression of a genetic mutation in a zebrafish model of aortic coarctation. Nat. Biotechnol. 22, 595-599. doi: 10.1038/ nbt963

Pietri, T., Manalo, E., Ryan, J., Saint-Amant, L., and Washbourne, P. (2009). Glutamate drives the touch response through a rostral loop in the spinal cord of zebrafish embryos. Dev. Neurobiol. 69, 780-795. doi: 10.1002/dneu. 20741

Pilorge, M., Fassier, C., Le Corronc, H., Potey, A., Bai, J., De Gois, S., et al. (2015). Genetic and functional analyses demonstrate a role for abnormal glycinergic signaling in autism. Mol. Psychiatry doi: 10.1038/mp.2015.139 [Epub ahead of print].

Pinto, D., Pagnamenta, A. T., Klei, L., Anney, R., Merico, D., Regan, R., et al. (2010). Functional impact of global rare copy number variation in autism spectrum disorders. Nature 466, 368-372. doi: 10.1038/nature09146

Pribilla, I., Takagi, T., Langosch, D., Bormann, J., and Betz, H. (1992). The atypical M2 segment of the beta subunit confers picrotoxinin resistance to inhibitory glycine receptor channels. EMBO J. 11, 4305-4311.

Quinlan, J. J., Ferguson, C., Jester, K., Firestone, L. L., and Homanics, G. E. (2002). Mice with glycine receptor subunit mutations are both sensitive and resistant to volatile anesthetics. Anesth. Analg. 95, 578-582. doi: 10.1213/00000539200209000-00016

Rajendra, S., Lynch, J. W., Pierce, K. D., French, C. R., Barry, P. H., and Schofield, P. R. (1995). Mutation of an arginine residue in the human glycine receptor transforms $\beta$-alanine and taurine from agonists into competitive antagonists. Neuron 14, 169-175. doi: 10.1016/0896-6273(95)90251-1 
Rees, M. I., Harvey, K., Ward, H., White, J. H., Evans, L., Duguid, I. C., et al. (2003). Isoform heterogeneity of the human gephyrin gene (GPHN), binding domains to the glycine receptor, and mutation analysis in hyperekplexia. J. Biol. Chem. 278, 24688-24696. doi: 10.1074/jbc.M301070200

Rees, M. I., Lewis, T. M., Kwok, J. B., Mortier, G. R., Govaert, P., Snell, R. G., et al. (2002). Hyperekplexia associated with compound heterozygote mutations in the $\beta$ subunit of the human inhibitory glycine receptor (GLRB). Hum. Mol. Genet. 11, 853-860. doi: 10.1093/hmg/11.7.853

Reichling, D. B., Kyrozis, A., Wang, J., and MacDermott, A. B. (1994). Mechanisms of GABA and glycine depolarization-induced calcium transients in rat dorsal horn neurons. J. Physiol. 476, 411-421. doi: 10.1113/jphysiol.1994.sp020142

Ribera, A. B., and Nüsslein-Volhard, C. (1998). Zebrafish touch-insensitive mutants reveal an essential role for the developmental regulation of sodium current. J. Neurosci. 18, 9181-9191.

Rigo, J. M., and Legendre, P. (2006). Frequency-dependent modulation of glycine receptor activation recorded from the zebrafish larvae hindbrain. Neuroscience 140, 389-402. doi: 10.1016/j.neuroscience.2006.01.057

Rizk, T. M., and Mahmoud, A. A. H. (2014). Novel GLRB gene mutation in a saudi baby with hyperekplexia. Pediatr. Neurol. 53, 54.

Roberts, A., Li, W. C., Soffe, S. R., and Wolf, E. (2008). Origin of excitatory drive to a spinal locomotor network. Brain Res. Rev. 57, 22-28. doi: 10.1016/j.brainresrev.2007.06.015

Rossi, A., Kontarakis, Z., Gerri, C., Nolte, H., Hölper, S., Krüger, M., et al. (2015). Genetic compensation induced by deleterious mutations but not gene knockdowns. Nature 524, 230-233. doi: 10.1038/nature14580

Saint-Amant, L., and Drapeau, P. (1998). Time course of the development of motor behaviors in the zebrafish embryo. J. Neurobiol. 37, 622-632. doi: 10.1002/(SICI)1097-4695(199812)37:4<622::AID-NEU10>3.0.CO;2-S

Saint-Amant, L., and Drapeau, P. (2001). Synchronization of an embryonic network of identified spinal interneurons solely by electrical coupling. Neuron 31, 1035-1046. doi: 10.1016/S0896-6273(01)00416-0

Salling, M. C., and Harrison, N. L. (2014). Strychnine-sensitive glycine receptors on pyramidal neurons in layers II/III of the mouse prefrontal cortex are tonically activated. J. Neurophysiol. 112, 1169-1178. doi: 10.1152/jn.00714.2013

Sander, J. D., Dahlborg, E. J., Goodwin, M. J., Cade, L., Zhang, F., Cifuentes, D., et al. (2011a). Selection-free zinc-finger-nuclease engineering by contextdependent assembly (CoDA). Nat. Methods 8, 67-69. doi: 10.1038/nmeth.1542

Sander, J. D., Cade, L., Khayter, C., Reyon, D., Peterson, R. T., Joung, J. K., et al. (2011b). Targeted gene disruption in somatic zebrafish cells using engineered TALENs. Nat. Biotechnol. 29, 697-698. doi: 10.1038/nbt.1934

Sassoè-Pognetto, M., Wassle, H., and Grunert, U. (1994). Glycinergic synapses in the rod pathway of the rat retina: cone bipolar cells express the alpha 1 subunit of the glycine receptor. J. Neurosci. 14, 5131-5146.

Scheer, N., and Campos-Ortega, J. A. (1999). Use of the Gal4-UAS technique for targeted gene expression in the zebrafish. Mech. Dev. 80, 153-158. doi: 10.1016/S0925-4773(98)00209-3

Schmid, K., Böhmer, G., and Gebauer, K. (1991). Glycine receptor-mediated fast synaptic inhibition in the brainstem respiratory system. Respir. Physiol. 84, 351-361. doi: 10.1016/0034-5687(91)90129-7

Schmid, K., Foutz, A. S., and Denavit-Saubié, M. (1996). Inhibitions mediated by glycine and GABA A receptors shape the discharge pattern of bulbar respiratory neurons. Brain Res. 710, 150-160. doi: 10.1016/0006-8993(95)01380-6

Schmitz, Y., Castagna, C., Mrejeru, A., Lizardi-Ortiz, J. E., Klein, Z., Lindsley, C. W., et al. (2013). Glycine transporter-1 inhibition promotes striatal axon sprouting via NMDA receptors in dopamine neurons. J. Neurosci. 33, 1677816789. doi: 10.1523/JNEUROSCI.3041-12.2013

Schmitz, Y., Luccarelli, J., Kim, M., Wang, M., and Sulzer, D. (2009). Glutamate controls growth rate and branching of dopaminergic axons. J. Neurosci. 29, 11973-11981. doi: 10.1523/JNEUROSCI.2927-09.2009

Schneider, V. A., and Granato, M. (2006). The myotomal diwanka (lh3) glycosyltransferase and type XVIII collagen are critical for motor growth cone migration. Neuron 50, 683-695. doi: 10.1016/j.neuron.2006.04.024

Schoonheim, P. J., Arrenberg, A. B., Del Bene, F., and Baier, H. (2010). Optogenetic localization and genetic perturbation of saccade-generating neurons in zebrafish. J. Neurosci. 30, 7111-7120. doi: 10.1523/JNEUROSCI.519309.2010

Schredelseker, J., Dayal, A., Schwerte, T., Franzini-Armstrong, C., and Grabner, M. (2009). Proper restoration of excitation- contraction coupling in the dihydropyridine receptor $\beta 1$-null zebrafi sh relaxed is an exclusive function of the $\beta$ 1a subunit. J. Biol. Chem. 284, 1242-1251. doi: 10.1074/jbc.M807767200

Schredelseker, J., Di Biase, V., Obermair, G. J., Felder, E. T., Flucher, B. E., FranziniArmstrong, C., et al. (2005). The $\beta 1$ a subunit is essential for the assembly of dihydropyridine- receptor arrays in skeletal muscle. Proc. Natl. Acad. Sci. U.S.A. 102, 17219-17224. doi: 10.1073/pnas.0508710102

Schwale, C., Schumacher, S., Bruehl, C., Titz, S., Schlicksupp, A., Kokocinska, M., et al. (2016). KCC2 knockdown impairs glycinergic synapse maturation in cultured spinal cord neurons. Histochem. Cell Biol 45, 637-646. doi: 10.1007/s00418-015-1397-0

Scott, E. K., Mason, L., Arrenberg, A. B., Ziv, L., Gosse, N. J., Xiao, T., et al. (2007). Targeting neural circuitry in zebrafish using GAL4 enhancer trapping. Nat. Methods 4, 323-326. doi: 10.1038/nmeth1033

Shen, H. Y., van Vliet, E. A., Bright, K. A., Hanthorn, M., Lytle, N. K., Gorter, J., et al. (2015). Glycine transporter 1 is a target for the treatment of epilepsy. Neuropharmacology 99, 554-565. doi: 10.1016/j.neuropharm.2015.08.031

Sidi, S., Friedrich, R. W., and Nicolson, T. (2003). NompC TRP channel required for vertebrate sensory hair cell mechanotransduction. Science 301, 96-99. doi: $10.1126 /$ science. 1084370

Simon, J., Wakimoto, H., Fujita, N., Lalande, M., and Barnard, E. A. (2004). Analysis of the set of GABAA receptor genes in the human genome. J. Biol. Chem. 279, 41422-41435. doi: 10.1074/jbc.M401354200

Singer, J. H., Talley, E. M., Bayliss, D. A., and Berger, A. J. (1998). Development of glycinergic synaptic transmission to rat brain stem motoneurons. J. Neurophysiol. 80, 2608-2620.

Sivasubbu, S., Balciunas, D., Davidson, A. E., Pickart, M. A., Hermanson, S. B., Wangensteen, K. J., et al. (2006). Gene-breaking transposon mutagenesis reveals an essential role for histone H2afza in zebrafish larval development. Mech. Dev. 123, 513-529. doi: 10.1016/j.mod.2006.06.002

Sola, M., Bavro, V. N., Timmins, J., Franz, T., Ricard-Blum, S., Schoehn, G., et al. (2004). Structural basis of dynamic glycine receptor clustering by gephyrin. EMBO J. 23, 2510-2519. doi: 10.1038/sj.emboj.7600256

Song, W., Chattipakorn, S. C., and McMahon, L. L. (2006). Glycine-gated chloride channels depress synaptic transmission in rat hippocampus. J. Neurophysiol. 95, 2366-2379. doi: 10.1152/jn.00386.2005

Specht, C. G., Grünewald, N., Pascual, O., Rostgaard, N., Schwarz, G., and Triller, A. (2011). Regulation of glycine receptor diffusion properties and gephyrin interactions by protein kinase C. EMBO J. 30, 3842-3853. doi: 10.1038/emboj.2011.276

Specht, C. G., Izeddin, I., Rodriguez, P. C., El Beheiry, M., Rostaing, P., Darzacq, X., et al. (2013). Quantitative nanoscopy of inhibitory synapses: counting gephyrin molecules and receptor binding sites. Neuron 79, 308-321. doi: 10.1016/j.neuron.2013.05.013

Steffen, L. S., Guyon, J. R., Vogel, E. D., Howell, M. H., Zhou, Y., Weber, G. J., et al. (2007). The zebrafish runzel muscular dystrophy is linked to the titin gene. Dev. Biol. 309, 180-192. doi: 10.1016/j.ydbio.2007.06.015

Stemple, D. L. (2004). TILLING-a high-throughput harvest for functional genomics. Nat. Rev. Genet. 5, 145-150. doi: 10.1038/nrg1273

Suli, A., Guler, A. D., Raible, D. W., and Kimelman, D. (2014). A targeted gene expression system using the tryptophan repressor in zebrafish shows no silencing in subsequent generations. Development 141, 1167-1174. doi: $10.1242 /$ dev. 100057

Takahashi, T., Momiyama, A., Hirai, K., Hishinuma, F., and Akagi, H. (1992). Functional correlation of fetal and adult forms of glycine receptors with developmental changes in inhibitory synaptic receptor channels. Neuron 9, 1155-1161. doi: 10.1016/0896-6273(92)90073-M

Tallini, Y. N., Ohkura, M., Choi, B. R., Ji, G., Imoto, K., Doran, R., et al. (2006). Imaging cellular signals in the heart in vivo: cardiac expression of the highsignal Ca2+ indicator GCaMP2. Proc. Natl. Acad. Sci. U.S.A. 103, 4753-4758. doi: 10.1073/pnas.0509378103

Tanimoto, M., Ota, Y., Horikawa, K., and Oda, Y. (2009). Auditory input to CNS is acquired coincidentally with development of inner ear after formation of functional afferent pathway in zebrafish. J. Neurosci. 29, 2762-2767. doi: 10.1523/JNEUROSCI.5530-08.2009

Tian, L., Hires, S. A., Mao, T., Huber, D., Chiappe, M. E., Chalasani, S. H., et al. (2009). Imaging neural activity in worms, flies and mice with improved GCaMP calcium indicators. Nat. Methods 6, 875-881. doi: 10.1038/ nmeth.1398 
Tsai, G., Ralph-Williams, R. J., Martina, M., Bergeron, R., Berger-Sweeney, J., Dunham, K. S., et al. (2004). Gene knockout of glycine transporter 1: characterization of the behavioral phenotype. Proc. Natl. Acad. Sci. U.S.A. 101, 8485-8490. doi: 10.1073/pnas.0402662101

Turecek, R., and Trussell, L. O. (2001). Presynaptic glycine receptors enhance transmitter release at a mammalian central synapse. Nature 411, 587-590. doi: $10.1038 / 35079084$

Tyagarajan, S. K., and Fritschy, J. M. (2014). Gephyrin: a master regulator of neuronal function. Nat. Rev. Neurosci. 15, 141-156. doi: 10.1038/nrn3670

Urnov, F. D., Miller, J. C., Lee, Y. L., Beausejour, C. M., Rock, J. M., Augustus, S., et al. (2005). Highly efficient endogenous human gene correction using designed zinc-finger nucleases. Nature 435, 646-651. doi: 10.1038/nature03556

Villefranc, J. A., Amigo, J., and Lawson, N. D. (2007). Gateway compatible vectors for analysis of gene function in the zebrafish. Dev. Dyn. 236, 3077-3087. doi: 10.1002/dvdy. 21354

Wang, C., Shimizu-Okabe, C., Watanabe, K., Okabe, A., Matsuzaki, H., Ogawa, T., et al. (2002). Developmental changes in KCC1, KCC2, and NKCC1 mRNA expressions in the rat brain. Dev. Brain Res. 139, 59-66. doi: 10.1016/S01653806(02)00536-9

Wang, F., Xiao, C., and Ye, J. H. (2005). Taurine activates excitatory non-synaptic glycine receptors on dopamine neurones in ventral tegmental area of young rats. J. Physiol. 565, 503-516. doi: 10.1113/jphysiol.2005.085423

Wang, M., Wen, H., and Brehm, P. (2008). Function of neuromuscular synapses in the zebrafish choline-acetyltransferase mutant bajan. J. Neurophysiol. 100, 1995-2004. doi: 10.1152/jn.90517.2008

Wässle, H., Heinze, L., Ivanova, E., Majumdar, S., Weiss, J., Harvey, R. J., et al. (2009). Glycinergic transmission in the Mammalian retina. Front. Mol. Neurosci. 2:6. doi: 10.3389/neuro.02.006.2009

Watanabe, E., and Akagi, H. (1995). Distribution patterns of mRNAs encoding glycine receptor channels in the developing rat spinal cord. Neurosci. Res. 23, 377-382. doi: 10.1016/0168-0102(95)00972-V

Weiss, J., O'sullivan, G. A., Heinze, L., Chen, H. X., Betz, H., and Wässle, H. (2008). Glycinergic input of small-field amacrine cells in the retinas of wildtype and glycine receptor deficient mice. Mol. Cell. Neurosci. 37, 40-55. doi: 10.1016/j.mcn.2007.08.012

Weltzien, F., Puller, C., O'Sullivan, G. A., Paarmann, I., and Betz, H. (2012). Distribution of the glycine receptor $\beta$-subunit in the mouse CNS as revealed by a novel monoclonal antibody. J. Comp. Neurol. 520, 3962-3981. doi: $10.1002 / \mathrm{cne} .23139$

White, R. M., Sessa, A., Burke, C., Bowman, T., LeBlanc, J., Ceol, C., et al. (2008). Transparent adult zebrafish as a tool for in vivo transplantation analysis. Cell Stem Cell 2, 183-189. doi: 10.1016/j.stem.2007.11.002

Wienholds, E., Schulte-Merker, S., Walderich, B., and Plasterk, R. H. (2002). Target-selected inactivation of the zebrafish ragl gene. Science 297, 99-102. doi: 10.1126/science. 1071762

Wienholds, E., Van Eeden, F., Kosters, M., Mudde, J., Plasterk, R. H., and Cuppen, E. (2003). Efficient target-selected mutagenesis in zebrafish. Genome Res. 13, 2700-2707. doi: 10.1101/gr.1725103

Winkelmann, A., Maggio, N., Eller, J., Caliskan, G., Semtner, M., Häussler, U., et al. (2014). Changes in neural network homeostasis trigger neuropsychiatric symptoms. J. Clin. Invest. 124, 696-711. doi: 10.1172/JCI71472

Xiong, W., Cui, T., Cheng, K., Yang, F., Chen, S. R., Willenbring, D., et al. (2012). Cannabinoids suppress inflammatory and neuropathic pain by targeting $\alpha 3$ glycine receptors. J. Exp. Med. 209, 1121-1134.

Yang, Z., Aubrey, K. R., Alroy, I., Harvey, R. J., Vandenberg, R. J., and Lynch, J. W. (2008). Subunit-specific modulation of glycine receptors by cannabinoids and N-arachidonyl-glycine. Biochem. Pharmacol. 76, 1014-1023. doi: 10.1016/j.bcp.2008.07.037
Yang, Z., Taran, E., Webb, T. I., and Lynch, J. W. (2012). Stoichiometry and subunit arrangement of $\alpha 1 \beta$ glycine receptors as determined by atomic force microscopy. Biochemistry 51, 5229-5231. doi: 10.1021/bi30 $0063 \mathrm{~m}$

Ye, J. H., Sokol, K. A., and Bhavsar, U. (2009). Glycine receptors contribute to hypnosis induced by ethanol. Alcohol. Clin. Exp. Res. 33, 1069-1074. doi: 10.1111/j.1530-0277.2009.00928.x

Ye, J. H., Wang, F., Krnjević, K., Wang, W., Xiong, Z. G., and Zhang, J. (2004). Presynaptic glycine receptors on GABAergic terminals facilitate discharge of dopaminergic neurons in ventral tegmental area. J. Neurosci. 24, 8961-8974. doi: 10.1523/JNEUROSCI.2016-04.2004

Young-Pearse, T. L., Ivic, L., Kriegstein, A. R., and Cepko, C. L. (2006). Characterization of mice with targeted deletion of glycine receptor alpha 2. Mol. Cell. Biol. 26, 5728-5734. doi: 10.1128/MCB.00237-06

Zeilhofer, H. U. (2005). The glycinergic control of spinal pain processing. Cell. Mol. Life Sci. 62, 2027-2035. doi: 10.1007/s00018-005-5107-2

Zeller, J., and Granato, M. (1999). The zebrafish diwanka gene controls an early step of motor growth cone migration. Development 126, 3461-3472.

Zeller, J., Schneider, V., Malayaman, S., Higashijima, S., Okamoto, H., Gui, J., et al. (2002). Migration of zebrafish spinal motor nerves into the periphery requires multiple myotome-derived cues. Dev. Biol. 252, 241-256. doi: 10.1006/dbio.2002.0852

Zhang, C., Rompani, S. B., Roska, B., and McCall, M. A. (2014). Adeno-associated virus-RNAi of GlyR $\alpha 1$ and characterization of its synapse-specific inhibition in OFF alpha transient retinal ganglion cells. J. Neurophysiol. 112, 3125-3137. doi: 10.1152/jn.00505.2014

Zhang, L. H., Gong, N., Fei, D., Xu, L., and Xu, T. L. (2008). Glycine uptake regulates hippocampal network activity via glycine receptor-mediated tonic inhibition. Neuropsychopharmacology 33, 701-711. doi: 10.1038/sj.npp. 1301449

Zhang, L. H., Xu, L., and Xu, T. L. (2006). Glycine receptor activation regulates short-term plasticity in CA1 area of hippocampal slices of rats. Biochem. Biophys. Res. Commun. 344, 721-726. doi: 10.1016/j.bbrc.2006.03.198

Zhang, Y., Dixon, C. L., Keramidas, A., and Lynch, J. W. (2015). Functional reconstitution of glycinergic synapses incorporating defined glycine receptor subunit combinations. Neuropharmacology 89, 391-397. doi: 10.1016/j.neuropharm.2014.10.026

Zhou, W., Saint-Amant, L., Hirata, H., Cui, W. W., Sprague, S. M., and Kuwada, J. Y. (2006). Non-sense mutations in the dihydropyridine receptor $\beta 1$ gene, CACNB1, paralyze zebrafish relaxed mutants. Cell Calcium 39, 227-236. doi: 10.1016/j.ceca.2005.10.015

Zhu, P., Narita, Y., Bundschuh, S. T., Fajardo, O., Zhang Schärer, Y. P., Chattopadhyaya, B., et al. (2009). Optogenetic dissection of neuronal circuits in zebrafish using viral gene transfer and the Tet system. Front. Neural Circuits 3:21. doi: 10.3389/neuro.04.021.2009

Zottoli, S. J. (1977). Correlation of the startle reflex and Mauthner cell auditory responses in unrestrained goldfish. J. Exp. Biol. 66, 243-254.

Conflict of Interest Statement: The authors declare that the research was conducted in the absence of any commercial or financial relationships that could be construed as a potential conflict of interest.

Copyright (c) 2016 Ogino and Hirata. This is an open-access article distributed under the terms of the Creative Commons Attribution License (CC BY). The use, distribution or reproduction in other forums is permitted, provided the original author(s) or licensor are credited and that the original publication in this journal is cited, in accordance with accepted academic practice. No use, distribution or reproduction is permitted which does not comply with these terms. 